\title{
Active surveillance for prostate cancer: A narrative review of clinical guidelines
}

Sophie M. Bruinsma, Chris H. Bangma, Peter R. Carroll, Michael S. Leapman, Antti Rannikko, Neophytos Petrides, Mahesha Weerakoon, Leonard P. Bokhorst, Monique J. Roobol, on behalf of the Movember GAP3 consortium

\begin{abstract}
In the past decade, active surveillance (AS) of men with localized prostate cancer has become an increasingly popular management option, and a range of clinical guidelines have been published on this topic. Existing guidelines regarding AS for prostate cancer vary widely, but predominantly state that the most suitable patients for AS are those with pretreatment clinical stage T1c or T2 tumours, serum PSA levels $<10 \mathrm{ng} / \mathrm{ml}$, biopsy Gleason scores of six or less, a maximum of one or two tumour-positive biopsy core samples and/or a maximum of 50\% of cancer per core sample. Following initiation of an AS programme, most guidelines recommend serial serum PSA measurements, digital rectal examinations and surveillance biopsies to check for and identify pathological indications of tumour progression. Definitions of disease reclassification and progression differ among guidelines and multiple criteria are proposed. The variety of descriptions of criteria for clinically insignificant prostate cancer indicates a lack of consensus on optimal AS and intervention thresholds. A single set of guidelines are needed in order to reduce variations in clinical practice and to optimize clinical decision-making. To enable truly evidence-based guidelines, further research that combines existing evidence whilst also gathering information from more long-term studies is needed.
\end{abstract}

Bruisma, S. M. et al. Nat. Rev. Urol.advance online publication XX Month 2016; doi:10.1038/

Department of Urology, Erasmus MC, P.O. Box 2040, 3000 CA Rotterdam, Netherlands (S.M.B., C.H.B, L.P.B., M.J.R.). Department of Urology, 550 16th Street, University of California, San Francisco, Mailbox Code 1695, San Francisco, CA 94143, USA (P.R.C., M.S.L). Department of Urology, Helsinki University Central Hospital, Haartmaninkatu 4, 00290 Helsinki, Finland (A.R.). Urology Research, University College London \& University College London Hospitals Trust, 132 Hampstead Road, London, NW1 2PS, UK (N.P.). Austin Hospital, Department of Surgery, Level 8 Harold Stokes Building, 145

Studley Road, Heidelberg VIC 3084, Australia (M.W.).

Correspondence to:

M.J.L.

$\underline{\text { m.roobol@erasmusmc.nl }}$ 


\section{Key points}

- A number of guidelines have been published that include criteria for active surveillance (AS) enrolment and subsequent management to assist clinicians and patients in critically important treatment related decision-making

- Consensus on inclusion criteria, surveillance schedules and intervention thresholds is currently lacking

- The future of AS and its uptake as a management modality will depend on better patient selection and validated monitoring schedules to improve identification of disease progression

- Combining existing evidence and gathering more long-term evidence is needed to derive a broadly supported guideline to reduce variations in clinical practice and to optimize clinical decision-making 


\section{Introduction [H1]}

Prostate cancer is the second most common form of cancer and the sixth leading cause of cancer-related mortality among men worldwide, with an estimated 899,000 new cases and 258,000 deaths in $2008^{1}$. The numbers of men living with a diagnosis of prostate cancer will continue to increase as the populations of many countries continue to age, and cancer is detected earlier, owing to the more widespread use of serum PSA testing and extended prostate biopsy techniques ${ }^{2}$. Findings from studies of the effects of prostate cancer screening have demonstrated a decrease in cancer-specific mortality in longitudinal monitoring periods. According to the latest 13-year follow-up results of the European Randomized Study of Screening for Prostate Cancer (ERSPC), systematic serum PSA-based screening for prostate cancer can reduce the incidence of death from prostate cancer by $21 \%$ compared with the control cohort, where no, or limited, use of screening was reported ${ }^{3}$. Measurement of serum PSA level has been used as a screening test for prostate cancer for $\geq 20$ years, although, the implementation of serum-PSA-based population screening remains controversial owing to the poor specificity of this biomarker, which frequently results in the incidental discovery of low-grade tumours that pose little risk of either metastatic spread or death ${ }^{4}$ 5, and are not likely to cause health problems during a man's lifetime. Overtreatment is a well-recognized consequence of the overdetection of prostate cancer, and is particularly problematic in individuals who are at a low risk of aggressive or lethal disease, who might be exposed to the morbidities of treatment with little or no benefit in terms of cancer-specific survival ${ }^{6}$.

Active surveillance (AS) focuses on the prevention of overtreatment by selecting patients with established features of low-risk prostate cancer and strictly monitoring these features over time in order to recognize a need for risk reclassification that would justify radical treatment, although still with a curative intent $^{7}$. The current challenge is to identify the specific subset(s) of patients that harbour more-aggressive disease, at a sufficiently early stage that curative therapy remains a possibility, thereby allowing the majority of patients with prostate cancer to retain their current quality of life, without experiencing the adverse effects of unnecessary treatments ${ }^{8}$.

Various institution-specific eligibility protocols have been proposed for the identification of patients for whom active surveillance would be appropriate ${ }^{2}$. Currently, published reports that contain formal protocols for AS are available for 16 unique cohorts of men with prostate cancer, worldwide ${ }^{9}$. Use of many different AS protocols has been reported in the literature, although these vary in both their inclusion criteria and monitoring procedures ${ }^{9}$. To date, the effectiveness of AS protocols has not been validated in randomized controlled trials. More importantly, these protocols have not been examined with respect to their effects upon overall and/or prostate cancer-specific mortality outcomes ${ }^{9}$. A reliable method for identifying tumours that are clinically insignificant is still lacking and triggers for the 
implementation of curative measures, such as radical prostatectomy and radiation treatments, have yet to be established.

A number of guidelines have been published to assist both clinicians and patients in critically important treatment related decision-making, these include criteria for enrolment of patients in AS programmes and their subsequent management ${ }^{10-25}$. However, the comparability of the recommendations contained in these various guidelines is unknown. In this Review, existing guidelines on the use of AS in men with clinically insignificant prostate cancer are described and compared, including a comprehensive overview of the recommendations regarding patient selection, frequency and type of monitoring and the criteria for initiation of definitive treatment.

\section{[H1] Characteristics of the guidelines}

Half of all published guidelines on AS of men with prostate cancer identified in our literature search were developed in Europe (eight) ${ }^{12,14-19,23}$; three in Canada ${ }^{10,20,24}$; two in the USA ${ }^{11,13}$; one in Asia ${ }^{21}$, one in New Zealand ${ }^{22}$ and one in Australia ${ }^{25}$ (Table 1). The guidelines were published between 2006 and 2015, and most of these have undergone subsequent updates. Most guidelines are published in English, except for the The Finnish Medical Society Duodecim (FCCG) ${ }^{23}$ and German Society of Urology (GSU) ${ }^{15}$ guidelines, which were published in Finnish and German, respectively. Almost all guidelines were on the diagnosis, treatment and/or the management of patients with prostate cancer in general and included information on AS only as an alternative management strategy ${ }^{10-17,19-23,25}$. Two organizations, the South East Scotland Cancer Network (SCAN) ${ }^{18}$ and Cancer Care Ontario (CCO) Evidence Based Guideline Quality Initiative ${ }^{24}$ have published guidelines that are specifically focused on AS.

\section{[H2] Quality assessment}

The Appraisal of Guidelines for Research and Evaluation (AGREE II) Instrument (http://www.agreetrust.org) ${ }^{26}$ is a validated generic tool designed for evaluation of the process of guideline development and provides a systematic framework for assessing key components of clinical guideline quality ${ }^{27}$. The instrument consists of 23 items grouped into six domains: scope and purpose; stakeholder involvement; rigour of development; clarity and presentation; applicability; and editorial independence ${ }^{27}$. One item is added to score the overall quality of the guideline. Each item is rated from one (strongly disagree or no information provided on this item) to seven (strongly agree) ${ }^{27}$. As outlined in the AGREE II manual, domain scores for AS protocols were calculated by summing all scores of the individual items in a domain, and by scaling the total as a percentage of the maximum possible score for that domain: ((obtained score - minimum possible score)/(maximum possible score - minimum possible 
score) $) \times 100$. Scores $>60 \%$ were defined as 'good', scores of $30-60 \%$ as 'moderate' and scores lower than $30 \%$ as 'poor' quality.

According to this assessment, 12 of the guidelines are of 'good' quality: those provided by the American urological association (AUA) ${ }^{13}$; the European Association of Urology (EAU) ${ }^{14}$; the National Comprehensive Cancer Network $(\mathrm{NCCN})^{11}$; the National Institute for Health and Clinical Excellence $(\mathrm{NICE})^{12}$; the $\mathrm{GSU}^{15}$; the Belgian Healthcare Knowledge Centre (KCE) ${ }^{17}$; the $\mathrm{FCCG}^{23}$; Cancer Care Nova Scotia (CCNS) ${ }^{10}$; Aragon Institute of Health Sciences $(\mathrm{I}+\mathrm{CS})^{19}$ CCO $^{24}$; the Prostate Cancer Taskforce $(\mathrm{PCT})^{22}$; and the Prostate Cancer Foundation of Australia (PCFA) ${ }^{25}$, and four guidelines are of 'moderate' quality: those provided by the Dutch Urological Association (DUA) ${ }^{16}$; the $\mathrm{SCAN}^{18}$; Alberta Health Services (AHS) ${ }^{20}$; and the Singapore Ministry of Health (NCCS) ${ }^{21}$. Inadequate and incomplete reporting cannot be ruled out as a reason for lower quality scores.

\section{[H2] Risk groups and surveillance}

Pretreatment risk estimation tools serve to stratify patients on the basis of perceived clinical risk and are employed in identifying candidates for AS. According to most of the guidelines described in this Review, patients with prostate cancer should be stratified into three risk groups: low, intermediate and high risk (Table 2), mostly based on tumour stage and grade, and serum PSA levels. The $\mathrm{NCCN}^{11}$ and the $\mathrm{PCT}^{22}$ additionally included 'very low risk' as a suitable risk profile of patients who are eligible for AS. According to recommendations contained in all guidelines included in this Review, AS is primarily recommended for patients with low-risk tumors. Various definitions of low-risk prostate cancer exist in these guidelines, as specified by different combinations of clinical criteria including clinical and pathological characteristics (such as tumour stage, serum PSA levels, biopsy Gleason score, tumor volume and serum PSA density). In certain guidelines, patients must possess numerous concurrent lowrisk features in order to be classified as 'low-risk', although in others, certain individual clinical criteria might lead to a patient being classified as having an intermediate, or high risk of tumour progression. Five guidelines, those provided by the $\mathrm{AUA}^{13}, \mathrm{NICE}^{12}, \mathrm{DUA}^{16}, \mathrm{FCCG}^{23}$, and $\mathrm{CCNS}^{10}$, contain recommendations to select intermediate-risk patients with prostate cancer for AS. Two of these guidelines — from the $\mathrm{AUA}^{13}$ and the DUA ${ }^{16}$ — state that AS also remains a treatment option for patients with 'high-risk' prostate cancer. Both of these guidelines specifically refer to AS and not to watchful waiting. In the AUA guidelines ${ }^{13}$, the term 'active surveillance' is used to refer to a monitoring program without initial treatment for patients with localized prostate cancer. This monitoring programme and its goals might be different based on specific patient and tumour characteristics and is distinct from watchful 
waiting, in which a lesser degree of monitoring is typically used, and treatment is generally instituted if metastases or symptoms develop ${ }^{13}$. The DUA guidelines ${ }^{16}$ also acknowledge a meaningful difference between AS and watchful waiting. In active surveillance, curative treatment is recommended if disease progression is detected, however, in watchful waiting the decision to start treatment relies on the progression of symptoms. The watchful waiting approach is typically used for the management of older patients who have substantial comorbidities. The DUA guidelines ${ }^{16}$ contain the recommendation that AS can be considered for patients with intermediate-risk or high-risk prostate cancer if the age of the patient and/or his comorbidities negatively influence life expectancy. According to the AUA guidelines ${ }^{13}$, patients with high-grade tumours generally have a poor prognosis and are not suitable for AS however, AS remains an option for the management of patients with high-risk localized prostate cancer, owing to the lack of evidence of superiority of any one therapy over another.

\section{[H1] Eligibility for active surveillance}

\section{[H2] Tumour characteristics}

\section{[H3] Clinical stage}

All of the guidelines described in this Review include information regarding the clinical stage of the prostate tumour as an eligibility criterion for AS. According to six of the guidelines, (those provided by the $\mathrm{NCCN}^{11}, \mathrm{KCE}^{17}, \mathrm{NCCS}^{21}, \mathrm{I}+\mathrm{CS}^{19}, \mathrm{CCO}^{24}$ and $\mathrm{PCT}^{22}$ ), AS is acceptable for patients with any tumours of stages T1 and T2a and also, according to the GSU guidelines ${ }^{15}$, for patients with tumours of stages T1c and T2a. The EAU guidelines ${ }^{14}$ include patients with stage T1c and any stage T2 tumours as being eligible for AS; the SCAN guidelines ${ }^{18}$ recommend inclusion of only patients with stage T1c tumours and the AHS guidelines ${ }^{20}$ recommend including those with $\leq \mathrm{T} 2 \mathrm{~b}$ stage tumours. Two guidelines (provided by NICE ${ }^{12}$ and the $\mathrm{FCCG}^{23}$ ) contain recommendations that patients with stage $\mathrm{T} 2 \mathrm{~b}$ tumours should be considered eligible for AS and three guidelines (provided by the $\mathrm{AUA}^{13}, \mathrm{CCNS}^{10}$ and $\mathrm{PCFA}^{25}$ ) also contain recommendations that patients with stage $\mathrm{T} 2 \mathrm{~b}-\mathrm{T} 2 \mathrm{c}$ tumours are eligible. The DUA guidelines ${ }^{16}$ also contain recommendations for use of AS (not watchful waiting), in patients with stage T3 tumours.

\section{[H3] Serum PSA}

All of the guidelines contain serum PSA-based criteria for eligibility for AS. Ten of the guidelines report a cutoff of $10 \mathrm{ng} / \mathrm{ml}$, above which, AS is not considered appropriate; seven of the guidelines (those provided by the $\mathrm{NCCN}^{11}, \mathrm{KCE}^{17}, \mathrm{SCAN}^{18}, \mathrm{AHS}^{20}, \mathrm{CCO}^{24}, \mathrm{NCCS}^{21}$ and the $\mathrm{PCT}^{22}$ ) are exclusive, and three (those provided by the EAU ${ }^{14}, \mathrm{GSU}^{15}$ and $\mathrm{I}+\mathrm{CS}^{19}$ ) are inclusive of this threshold. Three guidelines (those provided by $\mathrm{NICE}^{12}, \mathrm{FCCG}^{23}$ and $\mathrm{PCFA}^{25}$ ) also consider patients with serum PSA levels of 10-20 
$\mathrm{ng} / \mathrm{ml}$ to be eligible for AS and the CCNS guidelines ${ }^{21}$ include the same recommendation at $10-19 \mathrm{ng} / \mathrm{ml}$ serum PSA. The AUA ${ }^{13}$ and DUA ${ }^{16}$ guidelines allow selection of patients with serum PSA levels $>20$ $\mathrm{ng} / \mathrm{ml}$ for AS. Finally, five of the guidelines (those provided by the $\mathrm{NCCN}^{11}, \mathrm{SCAN}^{18}, \mathrm{I}+\mathrm{CS}^{19}, \mathrm{NCCS}^{21}$ and $\mathrm{PCT}^{22}$ ) include PSA density, which is the total serum PSA divided by the prostate volume, as an inclusion criterion for active surveillance, using a cutoff of $<0.15 \mathrm{ng} / \mathrm{ml}^{2}$.

\section{[H3] Biopsy Gleason score}

All of the guidelines described in this Review recommend Gleason score of a patient's biopsy sample(s) as a criterion for inclusion in AS programmes. Of these, 10 guidelines allow patients to have a Gleason score of $\leq 6$ (those provided by the $\mathrm{EAU}^{14}, \mathrm{NCCN}^{11}, \mathrm{GSU}^{15}, \mathrm{I}+\mathrm{CS}^{19}, \mathrm{NCCS}^{21}, \mathrm{PCT}^{22}$ and $\mathrm{PCFA}^{25}$ ) or, presented differently, $<7$ (those provided by the $\mathrm{KCE}^{17}$ and $\mathrm{AHS}^{20}$ ) or $\leq 3+3$ (the SCAN guidelines ${ }^{18}$ ). Four guidelines, those provided by $\mathrm{NICE}^{12}, \mathrm{CCNS}^{10}, \mathrm{CCO}^{24}$, and the $\mathrm{FCCG}^{23}$, consider patients with a Gleason score of 7 (mainly 3+4) eligible for AS and two guidelines support selection of patients with a Gleason score of $>7$ (those provided by the $\mathrm{AUA}^{13}$ and $\mathrm{DUA}^{16}$ ).

\section{[H3] Tumour Volume}

11 guidelines combine Gleason score, clinical tumour stage and serum PSA values with estimates of tumour load from analysis of biopsy specimens when considering patients for AS. Of the nine guidelines that include a recommendation based on the number of tumour-positive biopsy core samples, eight of these recommend a maximum of one or two tumour-positive biopsy core samples, either expressed as $<3$ (those provided by the $\mathrm{NCCN}^{11}, \mathrm{FCCG}^{20}, \mathrm{NCCS}^{26}$ and $\mathrm{PCT}^{27}$ ), one or two positive core samples (the $\mathrm{DUA}^{16}$ ) or $\leq 2$ (the $\mathrm{AUA}^{25}, \mathrm{EAU}^{14}$ and $\mathrm{GSU}^{15}$ ). One guideline (from the $\mathrm{AHS}^{20}$ ) suggests that patients with three tumour-positive biopsy cores should be considered eligible for AS.

Nine guidelines include the maximum extent of cancer, per biopsy core sample, as an inclusion criteria for active surveillance. All guidelines containing any consideration of the maximum extent of cancer use a cutoff of 50\%, of which three contain recommendations that are exclusive (those provided by the $\mathrm{SCAN}^{18}, \mathrm{I}+\mathrm{CS}^{19}$ and $\mathrm{PCT}^{27}$ ) and six that are inclusive of the threshold value (those provided by the $\mathrm{AUA}^{13}, \mathrm{EAU}^{14}, \mathrm{NCCN}^{11}, \mathrm{GSU}^{15}, \mathrm{AHS}^{20}$ and $\mathrm{NCCS}^{21}$ ). Three guidelines ( those provided by the AUA ${ }^{13}$,

$\mathrm{I}+\mathrm{CS}^{19}$, and $\mathrm{AHS}^{20}$ ) additionally state that a minimum of 10 prostate biopsy cores should be sampled and two guidelines ( those provided by the $\mathrm{GSU}^{15}$ and $\mathrm{FCCG}^{23}$ ) recommend a minimum core biopsy sample of $10-12$ cores.

\section{[H3] Patient characteristics}

Three guidelines (those provided by the $\mathrm{DUA}^{16}, \mathrm{FCCG}^{23}$ and $\mathrm{SCAN}^{18}$ ) include the patient's age as an inclusion criteria for active surveillance. The $\mathrm{SCAN}^{18}$ recommends a threshold of $\leq 75$ years, the $\mathrm{FCCG}^{23}$ 
guidelines refer to age as one of the variables to be considered when estimating patients life expectancy, and the DUA ${ }^{16}$ state that use of active surveillance is negotiable, if the age of the patient and his comorbidities negatively influence life expectancy.

Eight guidelines (those provided by the $\mathrm{EAU}^{14}, \mathrm{NCCN}^{11}, \mathrm{DUA}^{16}, \mathrm{KCE}^{17}, \mathrm{FCCG}^{23}, \mathrm{SCAN}^{18}$, $\mathrm{NCCS}^{21}$ and $\mathrm{PCT}^{22}$ ) include the patient's life expectancy as an inclusion criterion. All of these guidelines apply a cut-off time of 10 years. Most guidelines (including those provided by the $\left(\mathrm{EAU}^{14}, \mathrm{NCCN}^{11}\right.$, $\mathrm{KCE}^{17}$ and $\mathrm{SCAN}^{18}$ ) describe a life expectancy of $>10$ years as the ideal indication criterion for AS of patients with (very) low-risk prostate cancer. The EAU ${ }^{14}$ guidelines state that the patient's life expectancy can exceed 10 years once patients are informed of the lack of data on survival beyond 10 years. One set of guidelines (provided by the $\mathrm{NCCS}^{21}$ ) recommends use of AS in men with a shorter life expectancy, specifically $<10$ years. The other three guidelines (those provided by the $\mathrm{DUA}^{16}, \mathrm{FCCG}^{23}$ and $\mathrm{PCT}^{22}$ ) state that the patient's life expectancy should be taken into account, but do not provide further details.

Six guidelines (those provided by the AUA ${ }^{13}, \mathrm{DUA}^{16}, \mathrm{FCCG}^{23}, \mathrm{I}+\mathrm{CS}^{19}, \mathrm{NCCS}^{21}$ and $\mathrm{PCT}^{22}$ ) advise consideration of the presence of medical comorbidities and patients' bowel and genitourinary function, and quality of life status, in the decision making process ${ }^{13,16,19,21-23}$. Finally, eight guidelines (those provided by the $\mathrm{AUA}^{13}, \mathrm{NICE}^{12}, \mathrm{KCE}^{17}, \mathrm{FCCG}^{23}, \mathrm{I}+\mathrm{CS}^{19}, \mathrm{AHS}^{20}, \mathrm{NCCS}^{21}$ and $\mathrm{PCT}^{22}$ ) state that the decision to start AS should be made in the light of the patient's individual preferences.

\section{[H2] Summary of eligibility criteria}

Multiple criteria have been proposed for identifying patients with prostate cancer who have a favourable prognosis and are, therefore, candidates for AS (Table 3). Most available international guidelines recommend clinical risk stratification based on patients' tumour stage, serum PSA level, Gleason score, and estimated tumour volume as the primary means of refining patient selection. PSAD, the minimum number of prostate biopsy cores acquired, the patient's life expectancy, the presence of comorbidities and the patient's preferences have been advanced by some but have not, thus far, been universally adopted as risk stratification tools. Many variations in risk stratification schemes currently exist, guidelines predominantly recommend that the most suitable patients for active surveillance are those with pretreatment clinical stage T1(c) or T2a prostate cancer, serum PSA $<10 \mathrm{ng} / \mathrm{ml}$, biopsy Gleason score of six or less, a maximum of one or two tumour-positive biopsy core samples and/or a maximum of $50 \%$ of cancer per core.

\section{[H1] Surveillance type and frequency}

Of the 16 guidelines included, three guidelines (those provided by the $\mathrm{AUA}^{13}$, $\mathrm{DUA}^{16}$ and $\mathrm{PCFA}^{25}$ ) do not provide explicit recommendations for the monitoring of patients as part of an AS programme. 


\section{[H2] Serum PSA measurements}

Thirteen of the guidelines described in this Review recommend measurements of serum PSA during AS procedures. Four guidelines (those provided by the $\mathrm{NCCN}^{11}, \mathrm{KCE}^{17}, \mathrm{CCNS}^{10}$ and $\mathrm{PCT}^{22}$ ) state that serum PSA monitoring should be implemented at intervals longer than every 6 months after the start of AS. The $\mathrm{PCT}^{22}$ guidelines additionally state that serum PSA levels should be measured every 3 months if concerns about progression of the cancer exist. Three guidelines (those provided by the $\mathrm{AHS}^{20}, \mathrm{CCO}^{24}$ and $\mathrm{NCCS}^{21}$ ) recommend serum PSA testing every 3-6 months after the start of AS, whereas four of the other guidelines (those provided by $\mathrm{NICE}^{12}, \mathrm{GSU}^{15}, \mathrm{SCAN}^{18}$ and $\mathrm{I}+\mathrm{CS}^{19}$ ) use different frequencies depending on the time that has passed since the start of AS . Two of these guidelines (those provided by the GSU ${ }^{15}$ and SCAN $^{18}$ ) state that serum PSA should be measured every 3 months in the initial testing period of 1 year, and if the PSA level is stable within this period, then every 6 months subsequently. The I+CS ${ }^{19}$ guidelines recommend a serum PSA test every 3 months in the initial testing period of 2 years, and if the serum PSA level is stable within this period, then every 6 months subsequently. The NICE ${ }^{12}$ guidelines state that serum PSA levels should be checked every 3-4 months in the first year after commencing AS, and then every 3-6 months between 2-4 years and every 6 months in year 5 and thereafter. Finally, two guidelines (those provided by the $\mathrm{EAU}^{14}$ and $\mathrm{FCCG}^{23}$ ) recommend serum PSA testing during AS, but do not suggest any specific interval lengths between measurement.

\section{[H2] Digital rectal examination}

Thirteen of the guidelines described in this Review recommend the use of a digital rectal examination (DRE) in order to monitor the tumour carefully during a programme of AS. Four guidelines (those provided by the $\mathrm{NCCN}^{11}, \mathrm{AHS}^{20}, \mathrm{CCO}^{24}$ and $\mathrm{NCCS}^{21}$ ) recommend $\mathrm{DRE}$ at an interval of no more than once every 12 months. Another four guidelines (those provided by the $\mathrm{KCE}^{17}, \mathrm{SCAN}^{18}, \mathrm{CCNS}^{10}$ and $\mathrm{PCT}^{22}$ ) suggest more frequent DRE - every 6 months. The PCT guidelines ${ }^{22}$ additionally recommend that DRE should be performed every 3 months if concerns exist regarding tumour progression. Similar to serum PSA measurements, three guidelines (those provided by $\mathrm{NICE}^{12}, \mathrm{GSU}^{15}$ and $\mathrm{I}+\mathrm{CS}^{19}$ ) recommend the use of different intervals between successive DREs depending on the time that has passed since the start of AS. The NICE guidelines ${ }^{12}$ recommend that a DRE should be conducted every 6-12 months if patients have low-risk prostate cancer, and are undergoing AS within the first four years of diagnosis, with an annual DRE subsequent to this 4-year period. Two guidelines (provided by the $\mathrm{GSU}^{15}$ and $\mathrm{I}+\mathrm{CS}^{19}$ ) recommend a DRE every 3 months in the first 2 years after diagnosis, subsequently reducing to DRE at 6-monthly intervals thereafter (provided that serum PSA levels remain stable). Finally, two guidelines (those provided by the $\mathrm{EAU}^{14}$ and $\mathrm{FCCG}^{23}$ ) recommend use of DRE during active surveillance, but do not suggest any specific interval lengths between examinations. 


\section{[H2] Repeat biopsy sampling}

Repeat prostate biopsy sampling is used during AS in order to limit sampling error of the initial biopsy, that is, to confirm the initial biopsy findings and, periodically, to evaluate pathological progression of the tumour grade and/or volume, which might influence prognosis and, hence, the decision to continue AS or to proceed to definitive local therapy.

Substantial variation exists in the recommended frequency at which rebiopsy procedures should be conducted. A total of 13 of the guidelines described in this Review provide guidance in this area. The NCCN guidelines ${ }^{11}$ recommend intervals between biopsy sampling of at least 12 months, unless clinically indicated, or at 6 months if the initial biopsy procedure involved sampling of $<10$ cores or assessment discordant (e.g. palpable tumour contralateral to side of positive biopsy). Three guidelines (those provided by $\mathrm{NICE}^{12}, \mathrm{KCE}^{17}$ and the $\mathrm{PCT}^{22}$ ) recommend rebiopsy sampling at or within one year of diagnosis. According to the NICE ${ }^{12}$ and PCT guidelines ${ }^{22}$, the frequency of rebiopsy sampling should be dictated by changes in serum PSA levels or clinical concerns of tumour progression based on prostate changes detected by DRE. The KCE guidelines ${ }^{17}$ recommend the use of repeat biopsy sampling procedures, but also suggest that the optimal timing of such procedures cannot currently be defined. Seven guidelines (those provided by the $\mathrm{GSU}^{15}, \mathrm{SCAN}^{18}, \mathrm{CCNS}^{10}, \mathrm{I} \mathrm{CS}^{19}, \mathrm{AHS}^{20}, \mathrm{CCO}^{24}$ and $\mathrm{NCCS}^{21}$ ) recommend different frequencies of rebiopsy sampling depending upon the time that has passed since the start of AS. The AHS guidelines ${ }^{20}$ recommend repeat biopsy sampling at an interval of 1-2 years after the original diagnosis, and then every $2-3$ years thereafter, or as clinically indicated. The SCAN guidelines ${ }^{18}$ recommend considering rebiopsy sampling within 6 months of diagnosis, and then after 1, 4, 7 and 10 years of AS. The I+CS guidelines ${ }^{19}$ recommend rebiopsy sampling using a 1, 4 and 7 year timeframe, with at least 10 cores taken per biopsy procedure. The CCO guidelines ${ }^{24}$ recommend rebiopsy sampling with a 12-14-core confirmatory transrectal ultrasonography (TRUS) biopsy procedure (including anterior-directed cores) within 6-12 months of diagnosis, and serial biopsy a minimum of every 3-5 years thereafter. The NCCS guidelines ${ }^{21}$ suggest the use of rebiopsy sampling within 12-18 months and then less frequently thereafter. The EAU guidelines ${ }^{14}$ state that surveillance should, amongst other factors, be based upon the findings of repeat biopsy sampling, although the optimal timing of the various clinical measurements taken during AS is still unclear. Finally, the FCCG guidelines ${ }^{23}$ recommend use of repeat biopsy sampling during surveillance, but do not suggest any specific lengths of intervals between procedures.

\section{[H2] Other surveillance measures}

\section{[H3] PSA kinetics}


Seven guidelines (those provided by $\mathrm{NICE}^{12}, \mathrm{GSU}^{15}, \mathrm{FCCG}^{23}, \mathrm{SCAN}^{18}, \mathrm{I}^{+} \mathrm{CS}^{19}, \mathrm{AHS}^{20}$ and the $\mathrm{PCT}^{22}$ ) recommend including measurements of serum PSA kinetics in AS protocols, although none describe specific cut-off values. For example, the NICE guidelines ${ }^{12}$ state that serum PSA kinetics - which include PSA doubling time (PSADT) and PSA velocity (PSAV) - should be measured throughout AS, from the first year until 5 years and thereafter. The SCAN guidelines ${ }^{18}$ recommend calculating PSADT using a specific tool developed at the Memorial Sloan Kettering Cancer Center (https://www.mskcc.org/nomograms/prostate ), although only after five measurements of serum PSA levels have been obtained, including a measurement of baseline serum PSA.

\section{[H3] MRI}

According to four guidelines (those provided by the $\mathrm{NCCN}^{11}, \mathrm{NICE}^{12}, \mathrm{KCE}^{17}$ and $\mathrm{CCO}^{24}$ ), MRI might be considered for routine use in AS. According to the NCCN guidelines ${ }^{11}$, MRI may be performed in patients whose serum PSA levels have increased, despite the biopsy sample being found to be tumournegative on analysis. The NICE guidelines ${ }^{12}$ recommend that multiparametric MRI (mpMRI) should be performed at enrolment, (if not previously performed) or if the clinician is concerned about changes in clinical parameters or serum PSA levels at any time during AS. The KCE guidelines ${ }^{17}$ state that use of imaging can be considered each year. The CCO guidelines ${ }^{24}$ suggest that use of mpMRI is indicated when a patient's clinical findings are discordant with the pathological findings, and that MRI is useful in identifying occult cancers or changes indicative of tumour progression in patients who are at risk.

\section{[H2] Summary of surveillance type and frequency}

Following initiation of AS, most guidelines recommend serial measurment of serum PSA levels, digital rectal examination and surveillance biopsy sampling in order to identify pathological progression.

However, many uncertainties remain surrounding the optimal timing of these surveillance strategies. PSA kinetics and MRI are less frequently recommended as methods to identify whether or not a patients' cancer has progressed (Table 4).

\section{[H1] Switching to definitive therapy}

A proportion of men with ostensibly low-grade, low-stage prostate cancer who are undergoing AS will experience changes that will indicate a need for disease reclassification during extended surveillance ${ }^{28,29}$. As men's symptoms progress, or are reclassified beyond the initial inclusion criteria for active surveillance (they no longer meet the entry criteria), treatment with curative intent is often recommended. Definitions of tumour progression or reclassification vary among the published guidelines and a number of criteria have been proposed for determining when to proceed with curative interventions (Table 4). 
Five of the guidelines described in this study (those provided by the $\mathrm{AUA}^{25}, \mathrm{EAU}^{14}, \mathrm{DUA}^{16}, \mathrm{PCT}^{27}$ and the PCFA $^{10}$ ) do not include criteria for switching from AS to definitive therapy.

\section{[H2] Serum PSA measurements}

Two guidelines (those provided by the $\mathrm{GSU}^{15}$ and $\mathrm{KCE}^{17}$ ) describe an increase in serum PSA > $10 \mathrm{mg} / \mathrm{ml}$ as a trigger for intervention. According to these, and a further four guidelines (those provided by the $\mathrm{FCCG}^{23}, \mathrm{SCAN}^{18}, \mathrm{I} \mathrm{CS}^{19}$ and $\mathrm{AHS}^{20}$ ), changes in PSA kinetics can be assumed to be indicative of tumour progression. In five guidelines (those provided by the $\mathrm{GSU}^{15}, \mathrm{KCE}^{17}, \mathrm{FCCG}^{23}, \mathrm{SCAN}^{18}$ and $\mathrm{AHS}^{20}$ ) PSADT is recommended as a trigger for definitive intervention: all of these guidelines recommend commencing active treatment if PSADT is shorter than 3 years. One guideline describes PSA velocity as a trigger for intervention: if PSAV is $>1 \mathrm{ng} / \mathrm{ml}$ per year, then active treatment should be initiated.

\section{[H2] Digital rectal examination}

Five guidelines (those provided by the $\mathrm{GSU}^{15}, \mathrm{SCAN}^{18}, \mathrm{I} \mathrm{CS}^{19}, \mathrm{AHS}^{20}$ and $\mathrm{NCCS}^{21}$ ) include clinical progression, as confirmed by DRE as a trigger for switching from AS to treatment. According to the SCAN guidelines ${ }^{18}$, a finding of progression of palpable T2-stage disease on DRE or the appearance of palpable lesions is a criterion for intervention. The $\mathrm{GSU}^{15}$ recommends treatment if the clinical stage of the tumour increases to >cT2a. Four guidelines more generally state that treatment should be recommended: if there is an increase in clinical stage from baseline status ( $\mathrm{AHS}^{20}$ ), if an abnormal finding or change is detected on DRE $\left(\mathrm{NCCS}^{21}\right)$, if a clinical change is detected, in general, during DRE $\left(\mathrm{KCE}^{17}\right)$, or if locally advanced disease is detected during a DRE $\left(\mathrm{I}+\mathrm{CS}^{19}\right)$.

\section{[H2] Reclassification of biopsy sample grade}

Of all guidelines considered in this Review, eight (those provided by the $\mathrm{NCCN}^{30}, \mathrm{GSU}^{15}, \mathrm{FCCG}^{23}$, $\mathrm{SCAN}^{18}, \mathrm{I}+\mathrm{CS}^{19}, \mathrm{AHS}^{20}, \mathrm{CCO}^{24}$ and $\mathrm{NCCS}^{21}$ ) describe changes in the Gleason score of a prostate biopsy sample as a potential trigger for switching from surveillance to active therapy. According to four of these guidelines (those provided by the $\mathrm{NCCN}^{11}, \mathrm{SCAN}^{18}, \mathrm{AHS}^{20}$ and $\mathrm{NCCS}^{21}$ ), the appearance of primary or secondary Gleason 4 or any Gleason 5 pattern on rebiopsy is an indication to cease AS and consider intervention. Additionally, the GSU ${ }^{15}, \mathrm{FCCG}^{23}$ and NCCS guidelines ${ }^{21}$ recommend that all patients undergoing AS who are found to have a biopsy Gleason score of $>6$ (such as $\geq 3+4$ on analysis of a repeat biopsy sample should be considered for switching to active therapy. The $\mathrm{CCO}$ guidelines ${ }^{24}$ state that for patients with a Gleason score of $\geq 7$ and/or who also have substantial increases in the volume of Gleason 6 
tumour detected on analysis of a rebiopsy sample consideration should be given to switching to active therapy. The I+CS guidelines ${ }^{19}$ more generally recommend treatment in men with a higher degree and/or larger tumour volume observed in repeat biopsy samples relative to previous biopsy samples.

\section{[H2] Increase in tumour volume}

Three guidelines, those provided by the $\mathrm{GSU}^{15}, \mathrm{FCCG}^{23}$ and $\mathrm{NCCS}^{21}$, state that treatment should be recommended in men who have > 2 tumour-positive biopsy sample cores; and four guidelines (those provided by the $\mathrm{GSU}^{15}, \mathrm{SCAN}^{18}, \mathrm{AHS}^{20}$ and $\mathrm{NCCS}^{21}$ ) recommend that the extent of the cancer should not exceed 50\% per core, if AS is to be continued. The SCAN guidelines ${ }^{18}$ additionally recommend that $\leq 50 \%$ of the total number of cores should be affected by a patient's cancer for continued use of AS. Two guidelines (those provided by the $\mathrm{NCCN}^{30}$, and $\mathrm{I}+\mathrm{CS}^{19}$ ) contain more general descriptions. The NCCN guidelines state that an increase in the number of tumour-positive biopsy sample cores or an increase in the extent of disease in tumour-positive sample cores upon rebiopsy is a trigger for switching to treatment. The I+CS guidelines ${ }^{19}$ suggest a greater extension of the tumour in repeated biopsies. Four of the guidelines described in this Review (those provided by the $\mathrm{AUA}^{13}, \mathrm{GSU}^{15}, \mathrm{I}+\mathrm{CS}^{19}$ and $\mathrm{AHS}^{20}$ ) include information on the minimum number of biopsy cores that should be sampled and all agree on a minimum number of 10 cores.

\section{[H2] Other recommendations}

Two guidelines (those provide by $\mathrm{NICE}^{12}$ and the $\mathrm{NCCS}^{21}$ ), in general, recommend initiation of active treatment if disease progression is observed. Furthermore, the FCCG guidelines ${ }^{23}$ simply state that active treatment is recommended if a man's prostate cancer is reclassified as being clinically relevant. According to three guidelines (those provided by $\mathrm{NICE}^{12}$, the $\mathrm{AHS}^{20}$ and $\mathrm{NCCS}^{21}$ ), the decision to

proceed to radical treatment should be made on the basis of personal preferences ${ }^{12,20,21}$. According to the NICE guidelines ${ }^{12}$, the individual man's specific comorbidities and life expectancy should be taken into account when making a decision on proceeding to treatment.

\section{[H2] Summary of switching criteria}

Several of guidelines described in this Review do not include any criteria on switching from AS to definitive therapy. Definitions of disease reclassification and progression differ between different guidelines, and multiple criteria for initiation of treatment are proposed (Table 5). Some guidelines advocate the initiation of curative treatment if progression to a higher-grade tumour (mainly described as Gleason pattern 4 or 5 ) is observed, or if an increase in the number of tumour-positive biopsy cores (>2 of a recommended minimum of 10 cores) or an increase in the extent of cancer per core sample (to $>50 \%$ of 
cancer per tumour-positive core) is detected on analysis of surveillance biopsy samples. Clinical progression detected during DRE (although currently not clearly defined), a serum PSADT of $<3$ years, or a change in patient preference are also regularly described as risk reclassification criteria, leading to initiation of definitive treatment.

\section{[H1] Considering protocols overall}

In light of the high global prevalence of localized prostate cancer, AS has been widely implemented and numerous agencies have endorsed practice guidelines in this area. In total, 16 international guidelines advocate the use of AS as an initial option for disease management in men with localized prostate cancer, but many variations in recommended risk stratification schemes are found. Guidelines predominantly state that the most suitable patients for AS are those with pretreatment clinical stage T1(c) or T2 prostate cancer, serum PSA levels $<10 \mathrm{ng} / \mathrm{ml}$, biopsy Gleason scores of 6 or less, a maximum of one or two tumour-positive biopsy core samples and/or a maximum of $50 \%$ of cancer per biopsy core sample. Following initiation of AS, most guidelines advise the use of serial serum PSA measurements, DRE and surveillance biopsies to identify pathological tumour progression. The recommended intervals between these tests vary widely between guidelines. Definitions of disease reclassification and progression differed among guidelines and multiple criteria are proposed (Table 6).

AS is increasingly being accepted as a treatment option for patients with localized prostate cancer, although, robust data from men with clinically insignificant prostate cancer who are undergoing active surveillance guided by various protocols - especially from studies with long follow-up durations — is still limited. At present, two prospective AS studies have reported long-term outcomes of men with favorable-risk prostate cancer ${ }^{31,32}$. New data from the Johns Hopkins on outcomes after AS showed that factors associated with curative intervention were prostate specific antigen density at diagnosis and a higher number of positive biopsy cores at diagnosis ${ }^{31}$. Klotz et al found that in a Canadian active surveillance cohort, followed up for 16 years, PSADT of less than 3 years is a marker for aggressive disease $^{32}$. Further, only data from prospective clinical trials of active surveillance, that have a mean follow-up duration of $<10$ years are available ${ }^{33}$. This lack of robust evidence is reflected in the diversity of recommendations among the available guidelines on AS of men with clinically insignificant prostate cancer. Findings of a study conducted by Azmi et al. ${ }^{34}$ in 2013 showed that a relatively high level of agreement exists between the conclusions of various studies of AS that patients with serum PSA levels $\leq 10 \mathrm{ng} / \mathrm{ml}$ and a biopsy sample Gleason score of $\leq 3+3=6$ are appropriate for AS, although, clearly less agreement exists in terms of the most appropriate clinical tumour stage, number of tumour-positive

biopsy core samples and patient age ${ }^{34}$. Furthermore, little consensus exists in the literature regarding how to optimally assess progression of localized prostate cancer; although, the majority of studies used serial 
measurements of serum PSA levels and DRE, with some also adding prostate biopsy sampling ${ }^{34}$. No consensus has been reached regarding the frequency of repeat investigations or on the most appropriate triggers for initiation of radical treatment across the various AS programmes ${ }^{34}$. To enable truly evidencebased guidelines to be issued, further research that combines existing evidence whilst also gathering information from more long-term studies is needed.

Patients with prostate cancer who have a tumour grade of Gleason $\leq 6$ are extremely unlikely to progress to metastatic disease or die from their cancer ${ }^{35}$. However, some guidelines have taken the position that AS could be an appropriate management strategy for men with a Gleason score of $\geq 7$ at diagnosis ${ }^{10,12,13,16,23,24}$. Findings from a study with a large cohort demonstrate that the finding of a Gleason score of 8-10 on confirmatory biopsy is associated with early progression to metastasis ${ }^{32}$. The AUA guidelines ${ }^{13}$ acknowledge these high rates; however, these guidelines still recommend AS as a treatment option for patients with high-risk disease owing to the lack of evidence of superiority of any one therapy over another. Whether this approach is the correct one to follow is a matter of some debate.

Explanations for the observed variations between available guidelines for AS are speculative, but geographical variations should be taken into account. Different countries practice medicine in various ways and vary particularly in their approaches to the treatment of cancer ${ }^{36}$. These differences are likely a result of the existence of distinct national cultures, history and medical training ${ }^{36}$. For instance, major differences exist between the detection and treatment of prostate cancer in the USA and UK. Widespread use of serum-PSA based screening in the USA has resulted in a higher proportion of men being diagnosed with disease that is amenable to $\mathrm{AS}^{37,38}$. In the UK - a country with relatively limited use of serum-PSA based screening - only a small minority of newly diagnosed patients with prostate cancer meet the criteria for low-risk disease ${ }^{39}$. An aggressive local philosophy with respect to prostate cancer screening might also correspond with an increased tendency towards treatment ${ }^{40}$. In the USA, academic medical community and professional societies have become more accepting of AS for men with low-risk prostate cancer, although delaying the initiation of aggressive treatment is still not generally acceptable to most patients or their doctors ${ }^{38}$. By contrast, findings of a UK study published in 2010 showed that British men and doctors were more willing to accept AS with up to $39 \%$ opting for AS in recent years ${ }^{39}$. The various available guidelines highlight the best practices for the diagnosis, treatment and/or the management of prostate cancer in different geographical areas. Whether or not these cross-cultural differences will ever be perfectly integrated into one global policy remains questionable.

The validation and clinical implementation of novel biomarkers might improve the identification of the most appropriate candidates for AS and will likely be reflected in future guidelines. Van den Bergh et $a l^{41}$ concluded that imaging and serum-based markers (such as PSA isoforms) might, in the future, improve the selection of patients for AS and follow-up monitoring during active surveillance ${ }^{41}$. In a 
review published in 2014, authors noted that a growing body of literature is available on patient characteristics, biopsy features and biomarkers with potential utility in $\mathrm{AS}^{42}$. For instance, patient age, race, and possibly family history are all factors that could be considered for patient selection. Also, consistent evidence suggests that a lower percentage free PSA, higher Prostate Health Index, higher PSAD and greater biopsy core involvement at baseline all indicate a greater risk of progression ${ }^{42}$. Furthermore, evidence suggests that use of the biopsy-based 17-gene Genomic Prostate Score improves prediction of the presence or absence of adverse pathology and might help men with prostate cancer to make better-informed choices between AS and immediate treatment ${ }^{43}$. Following various advances in genomic and proteomic technologies, several new Clinical Laboratory Improvement Amendment-based laboratory-developed tests have become available that might also be useful in the differentiation of aggressive from nonaggressive forms of prostate cancer, such as Prolaris ${ }^{\circledR}$ (Myriad Genetics, Salt Lake City, UT USA) ${ }^{44}$. The 4 Kscore $^{\circledR}$ (Opko Health, FL, USA) has also been shown to have proven diagnostic performance when used for detection of clinically significant prostate cancer and might be a useful tool in distinguishing men who have clinically significant disease and are most likely to benefit from a prostate biopsy from men with no cancer or indolent cancer ${ }^{45}$. In a systematic review on the use of MRI in men with low-risk or intermediate-risk prostate cancer who were considered suitable for AS, the researchers demonstrated that MRI is useful for the detection of clinically significant disease at initial clinical assessment of men considering $\mathrm{AS}^{46}$. In addition, MRI might be useful to confirm the absence of any large anterior lesions that have been missed during routine diagnosis ${ }^{47}$. However, at present, no robust, formally published data are available that support the use of MRI in place of repeat standard biopsy sampling to detect progression of cancer over time ${ }^{46}$. Among biopsy sampling approaches, transrectal prostate biopsy sampling (TRB) is internationally more common than transperineal prostate biopsy sampling (TPB). Findings of a study published in 2013, however, suggest that, in patients on AS programmes, a staging TPB might be an alternative approach for patients undergoing repeat biopsy in order to minimize the risk of serious infection ${ }^{48}$. Whether any role exists for these markers and monitoring tools in risk assessment during AS requires further study. . Finally, quality of life, arguably, should have a role in the decision to initially pursue AS rather than active treatment and in the decision to switch from AS to active treatment ${ }^{49}$. However, no data from studies with long-term follow-up durations and suitable control groups are currently available and more research is needed in this area. AS is currently an evolving treatment approach, with numerous challenges (Box 2). Thus, it is advised that guideline writers should carefully follow the progress that is made within the field of AS, as the field is moving rapidly. 
[H1] Challenges in reviewing AS guidelines

The use of electronic sources to identify guidelines for discussion in this Review might have introduced bias towards English language guidelines and guidelines produced by larger, well-established $\operatorname{organizations}^{50}$. The use of high-quality guidelines would improve health-related decision making, potentially resulting in enhanced health care quality and outcomes. Our own assessment using the AGREE II tool suggests that not all of the included guidelines are of 'good' quality. It could be argued if guidelines of 'moderate' quality should be used for patient care. Users of clinical practice guidelines need to know how much confidence they can place in the recommendations. Furthermore, the guidelines described in this Review have been developed by a number of leading organizations using different methodologies. For instance, discrepancies exist in the criteria used to grade the quality of evidence and to categorize the strength of the recommendations. These differences could be the source of conflicting recommendations ${ }^{51}$. Standardizing the processes used by leading urological organizations to develop clinical guidelines for the management of patients with prostate cancer would be beneficial to both clinicians and patients (Box 3) ${ }^{51}$. Finally, substantial variation was observed in the year of publication of individual sets of guidelines, with several were published more than 5 years ago, which could mean these are no longer in line with current clinical practice, thus leaving it up to clinicians to make up their own minds about how they manage patients on AS.

\section{[H1]Future steps}

Clearly, an unmet need exists for a worldwide consensus regarding criteria and protocols for AS. When developing a global guideline, the selection of topics, the composition of the guideline group, the work plan, the search for evidence and the involvement of clinical experts are all important ${ }^{52}$. An evidencebased consensus approach to developing guideline recommendations is considered the 'gold standard'. The development phase should, therefore, start by searching for scientific evidence and an assessment of its relevance and quality. As a next step, clinical experts should be involved to formulate and prioritize recommendations ${ }^{52}$. Owing to the possibility of one, or a few experts could dominating discussions according to their own individual origin, background and experiences, structuring the discussions is recommended, for instance by using the Delphi Procedure ${ }^{53}$ to quantitate 'expert opinion'. The entire process of developing guidelines should be transparent to the guideline user. The principal benefit of a global guideline is to improve the consistency of (high-quality) care. However, constructing a global guideline presents a unique challenge. Approaches to AS of men with prostate cancer differ across the world, the guideline should, therefore be both comprehensive and flexible enough to allow adaptation to the diverse settings and circumstances of day-to-day clinical practice. The development and publication of a set of global clinical practice guidelines are only the first steps in the process of improving patient care. 
To facilitate the applicability of such guidelines in daily care, co-operation with professional societies and associations is crucial. The clinical guideline should ideally be submitted for approval to an independent scientific council and to the professional urological organizations responsible ${ }^{52}$. Furthermore, collaboration should be sought with patient advocacy organizations, who could have an important role in promoting the guidelines among patients and their families.

One potential solution is the Movember Global Action Plan Active Surveillance project (GAP3), which was launched in August 2014. This initiative is an integrated project lasting 30 months and is being implemented across 19 institutions in 14 countries, and across five Movember regions (Australasia, Europe, UK, Canada, USA), as well as being open to other eligible centres ('candidate centres'). GAP3 aims to create a global consensus on selection and monitoring of men with low-risk prostate cancer for AS; provide and manage a worldwide platform with information and guidelines on AS as an acknowledged treatment option for prostate cancer, and to reduce the number of men switching to active therapy within 1 year of starting the AS protocol. Milestones of the project include a global AS database for clinical, biopsy sample, imaging and biomarker data (including a virtual biobank), as well as worldwide tailor-made guidelines, including a web-based platform on AS. At this stage, active surveillance 'is a treatment approach in evolution.' This initiative will make significant contributions to this field of research by offering standard, evidence-based guidelines on AS. Clinicians will be able to use these guidelines to more confidently identify men that are suitable for active surveillance and to also decide whose prostate cancer has progressed and will, therefore, require treatment. Such guidelines will provide reassurance to men that they have made the best treatment choice for their type of disease.

\section{[H1] Conclusions}

Despite the ample availability of guidelines on AS for patients with prostate cancer, consensus on inclusion criteria, surveillance schedules and intervention thresholds is currently lacking. The future of AS and its uptake as a management modality will depend on better patient selection and validated monitoring schedules to improve the identification of disease progression. Combining existing evidence and gathering more long-term evidence is needed in order to derive a broadly supported guideline to reduce variation in clinical practice and to optimize clinical decision-making. 


\section{References}

1. Center, M.M. et al. International variation in prostate cancer incidence and mortality rates. EUR UROL 61, 1079-92 (2012).

2. Kim, T.H. et al. Pathological upgrading and upstaging of patients eligible for active surveillance according to currently used protocols. Int J Urol (2013).

3. Schroder, F.H. et al. Screening and prostate cancer mortality: results of the European Randomised Study of Screening for Prostate Cancer (ERSPC) at 13 years of follow-up. Lancet (2014).

4. Duffy, M.J. PSA in screening for prostate cancer: more good than harm or more harm than good? Adv Clin Chem 66, 1-23 (2014).

5. Stenman, U.H. et al. Prognostic value of serum markers for prostate cancer. Scand J Urol Nephrol Suppl, 64-81 (2005).

6. Hugosson, J. \& Carlsson, S. Overdetection in screening for prostate cancer. Curr Opin Urol 24, 256-63 (2014).

7. Bul, M. et al. Active surveillance for low-risk prostate cancer worldwide: the PRIAS study. EUR UROL 63, 597-603 (2013).

8. Klotz, L. Active surveillance for prostate cancer: patient selection and management. Curr Oncol 17 Suppl 2, S11-7 (2010).

9. Ip, S. et al. An evidence review of active surveillance in men with localized prostate cancer. Evid rep/technol assess, 1-341 (2011).

10. Cancer Care Nova Scotia (CCNS) (2006). Guidelines for the Management of Prostate Cancer. http://www.cancercare.ns.ca/sitecc/media/cancercare/ProstateGuidelinesFullVersion2006(1).pdf [accessed 24 Jan 2015].

11. The National Comprehensive Cancer Network (NCCN) (2014). NCCN Clinical Practice Guidelines in Oncology. Prostate Cancer. http://www.trikobe.org/nccn/guideline/urological/english/prostate.pdf. Accessed 14 Jan 2015.

12. The National Institute for Health and Clinical Excellence (NICE) (2014) Prostate cancer: diagnosis and treatment. http://www.nice.org.uk/guidance/cg175/resources/guidance-prostate-cancerdiagnosis-and-treatment-pdf. accessed 25 May 2015.

13. American Urological Association (AUA) (2007). Guideline for the Management of Clinically Localized Prostate Cancer: 2007 update. http://www.auanet.org/common/pdf/education/clinical-guidance/Prostate-Cancer.pdf. Accessed 4 Feb 2015.

14. European Association of Urology (EAU) (2016). Guidelines on prostate cancer. http://uroweb.org/guideline/prostate-cancer/. Accessed 1 August 2016.

15. German Society of Urology (GSU) (2014). Interdisziplinäre Leitlinie der Qualität S3 zur Früherkennung, Diagnose und Therapie der verschiedenen Stadien des Prostatakarzinoms. https://www.urologenportal.de/fileadmin/MDB/PDF/konsultationsfassung-leitlinieprostatakarzinom.pdf. Accessed January 182015.

16. Dutch Urological Association (DUA) (2014). Richtlijn prostaatcarcinoom. http://richtlijnendatabase.nl/richtlijn/prostaatcarcinoom/algemeen.html. Accessed Jan 282015.

17. Belgian Healthcare Knowledge Centre (KCE) (2013). A national clinical practice guideline on the management of localised prostate cancer. http://kce.fgov.be/sites/default/files/page documents/KCE 194C prostate cancer 0.pdf. Accessed 5 March 2015.

18. South East Scotland Cancer Network (SCAN) (2009). SCAN Guideline for Active Surveillance (Deferred Radical Treatment) of Early, Low-Risk, Prostate Cancer. 
http://www.scan.scot.nhs.uk/Documents/SCAN\%20Protocol\%20for\%20Active\%20Surveillance\% 20of\%20Early\%20Prostate\%20Cancer\%20-\%2017072009.pdf. Accessed 5 february 2015.

19. Aragon Institute of Health Sciences (I+CS) (2008). Clinical Practice Guideline for Prostate Cancer Treatment. http://www.guiasalud.es/GPC/GPC 431 Prostate Ca ICS compl en.pdf. Accessed 10 February 2015.

20. Alberta Health Services (AHS) (2013). Alberta Health Services Clinical Practice Guideline: Prostate Cancer. http://www.albertahealthservices.ca/hp/if-hp-cancer-guide-gu004prostate.pdf. Accessed 4 May 2015.

21. Singapore Ministry of Health (NCCS) (2014). Guidelines on Management of Prostate Cancer. http://www.annals.edu.sg/pdf/42VolNo4Apr2013/V42N4p190.pdf. Accessed 4 May 2015.

22. Prostate Cancer Taskforce (PCT) (2012). Diagnosis and Management of Prostate Cancer in New Zealand Men: Recommendations from the Prostate Cancer Taskforce.

http://www.health.govt.nz/system/files/documents/publications/diagnosis-managementprostate-cancer-nz-men.pdf. Accessed 4 May 2015.

23. The Finnish Medical Society Duodecim (FCCG) (2014). Prostate cancer (Eturauhassyöpä). http://www.scan.scot.nhs.uk/Documents/SCAN\%20Protocol\%20for\%20Active\%20Surveillance\% 20of\%20Early\%20Prostate\%20Cancer\%20-\%2017072009.pdf. Accessed 4 May 2015.

24. Cancer Care Ontario (CCO) Evidence Based Guideline Quality Initiative (2015). Active Surveillance for the Management of Localized Prostate Cancer: Guideline Recommendations. http://journals.sfu.ca/cuaj/index.php/journal/article/view/2806/2208. Accessed Aug 27 2015. .

25. Prostate Cancer Foundation of Australia and Cancer Council Australia PSA Testing Guidelines Expert Advisory Panel. Draft clinical practice guidelines PSA Testing and Early Management of Test-Detected Prostate Cancer. Sydney: Cancer Council Australia. [Version URL: http://wiki.cancer.org.au/australiawiki/index.php?oldid=106555, cited 2015 Jun 4]. Available from: http://wiki.cancer.org.au/australia/Guidelines:PSA Testing/Active surveillance.

26. AGREE Next Steps Consortium. The AGREE II Instrument [Electronic version] 2009. http://www.agreetrust.org (accessed January 2015).

27. Joosen, M.C. et al. An international comparison of occupational health guidelines for the management of mental disorders and stress-related psychological symptoms. Occup Environ Med (2014).

28. Dall'era, M.A. et al. Active surveillance for early-stage prostate cancer: Review of the current literature. Cancer 112, 1650-1659 (2008).

29. Welty, C.J. et al. Extended followup and risk factors for disease reclassification in a large active surveillance cohort for localized prostate cancer. J UROL 193, 807-11 (2015).

30. National Comprehensive Cancer Network (NCCN). NCCN Clinical practice guidelines in oncology. http://www.nccn.org/professionals/physician gls/f guidelines.asp (Accessed on April 01, 2014).

31. Tosoian, J.J. et al. Intermediate and Longer-Term Outcomes From a Prospective ActiveSurveillance Program for Favorable-Risk Prostate Cancer. J Clin Oncol 33, 3379-85 (2015).

32. Klotz, L. et al. Long-term follow-up of a large active surveillance cohort of patients with prostate cancer. J Clin Oncol 33, 272-7 (2015).

33. Lund, L., Svolgaard, N. \& Poulsen, M.H. Prostate cancer: a review of active surveillance. Res Rep Urol 6, 107-12 (2014).

34. Azmi, A. et al. Active surveillance for low-risk prostate cancer: diversity of practice across Europe. Ir J Med Sci (2014).

35. Kweldam, C.F., Wildhagen, M.F., Bangma, C.H. \& van Leenders, G.J. Disease-specific death and metastasis do not occur in patients with Gleason score $</=6$ at radical prostatectomy. BJU Int 116, 230-5 (2015). 
36. L, P. Medicine Culture: Varieties of treatment in the United States, England, West Germany, and France. (Henry Holt and Company, New York, 1989).

37. Welch, H.G. \& Albertsen, P.C. Prostate cancer diagnosis and treatment after the introduction of prostate-specific antigen screening: 1986-2005. J Natl Cancer Inst 101, 1325-9 (2009).

38. Xu, J., Neale, A.V., Dailey, R.K., Eggly, S. \& Schwartz, K.L. Patient perspective on watchful waiting/active surveillance for localized prostate cancer. J Am Board Fam Med 25, 763-70 (2012).

39. McVey, G.P. et al. Initial management of low-risk localized prostate cancer in the UK: analysis of the British Association of Urological Surgeons Cancer Registry. BJU Int 106, 1161-4 (2010).

40. Cooperberg, M.R., Broering, J.M. \& Carroll, P.R. Time trends and local variation in primary treatment of localized prostate cancer. J Clin Oncol 28, 1117-23 (2010).

41. van den Bergh, R.C. et al. Novel Tools to Improve Patient Selection and Monitoring on Active Surveillance for Low-risk Prostate Cancer: A Systematic Review. EUR UROL (2014).

42. Loeb, S. et al. Active Surveillance for Prostate Cancer: A Systematic Review of Clinicopathologic Variables and Biomarkers for Risk Stratification. EUR UROL (2014).

43. Klein, E.A. et al. A 17-gene assay to predict prostate cancer aggressiveness in the context of Gleason grade heterogeneity, tumor multifocality, and biopsy undersampling. EUR UROL 66, 550-60 (2014).

44. $\quad$ Sartori, D.A. \& Chan, D.W. Biomarkers in prostate cancer: what's new? Curr Opin Oncol 26, 25964 (2014).

45. Parekh, D.J. et al. A Multi-institutional Prospective Trial in the USA Confirms that the 4Kscore Accurately Identifies Men with High-grade Prostate Cancer. EUR UROL (2014).

46. Schoots, I.G. et al. Magnetic Resonance Imaging in Active Surveillance of Prostate Cancer: A Systematic Review. EUR UROL (2014).

47. Sankineni, S., Osman, M. \& Choyke, P.L. Functional MRI in prostate cancer detection. Biomed Res Int 2014, 590638 (2014).

48. Symons, J.L. et al. Outcomes of transperineal template-guided prostate biopsy in 409 patients. BJU Int 112, 585-93 (2013).

49. Bellardita, L. et al. How Does Active Surveillance for Prostate Cancer Affect Quality of Life? A Systematic Review. EUR UROL (2014).

50. McIntosh, H.M. et al. Follow-up care for men with prostate cancer and the role of primary care: a systematic review of international guidelines. Br J Cancer 100, 1852-60 (2009).

51. Dahm, P., Yeung, L.L., Chang, S.S. \& Cookson, M.S. A critical review of clinical practice guidelines for the management of clinically localized prostate cancer Review. J UROL 180, 451-459; discussion 460 (2008).

52. Wollersheim, H., Burgers, J. \& Grol, R. Clinical guidelines to improve patient care. Neth J Med 63, 188-92 (2005). 


\section{Acknowledgements}

This study is linked to a larger project, the Movember Foundation's Global Action Plan on active surveillance for low-risk prostate cancer (GAP3), which is collaboration between institutions, hospitals and research centres in Australia, Canada, France, Finland, Italy, Japan, Netherlands, UK and the USA. The Movember Foundation has invested $€ 1,664,950$ in the GAP3 project in order to create the largest centralized database on AS in men with prostate cancer to date, comprising around $40 \%$ of all global patient data on AS. The funder did not play any role in the study design, collection, analysis or interpretation of data, or in the drafting of this paper.

\section{Author contributions}

Study concept and design: Sophie M. Bruinsma, Chris H. Bangma, Peter R. Carroll, Antti Rannikko, Monique J. Roobol, the Movember GAP3 consortium

Acquisition of data: Sophie M. Bruinsma, Michael S. Leapman, Neophytos Petrides, Mahesha Weerakoon, Leonard P. Bokhorst

Analysis and interpretation of data: Sophie M. Bruinsma, Chris H. Bangma, Peter R. Carroll, Michael S. Leapman, Antti Rannikko, Neophytos Petrides, Mahesha Weerakoon, Leonard P. Bokhorst, Monique J. Roobol

Drafting of the manuscript: Sophie M. Bruinsma, Michael S. Leapman, Neophytos Petrides, Mahesha Weerakoon, Leonard P. Bokhorst

Critical revision of the manuscript for important intellectual content: Sophie M. Bruinsma, Chris H. Bangma, Peter R. Carroll, Michael S. Leapman, Antti Rannikko, Neophytos Petrides, Mahesha Weerakoon, Leonard P. Bokhorst, Monique J. Roobol, the Movember GAP3 consortium Statistical analysis: None.

\section{Competing interests}

The authors declare no competing interests.

\section{Review criteria}

Several strategies were used to identify relevant guidelines on active surveillance for localized prostate cancer. In April 2014, electronic searches were performed in Medline, Cochrane Central Register of Controlled Trials (CENTRAL), Web of Science, CINAHL, PubMed and Google scholar online databases. A search strategy was developed in collaboration with an experienced librarian for relevant publications. The search string was initially developed in Embase and later adapted for other databases (see appendix 1 for the full search strategy). The search covered literature published between 2001 and 2014. The goal of 
this study was to provide a comprehensive overview of existing guidelines, therefore, no restrictions were made with regards to nonempirical studies such as literature reviews and conference abstracts. To retrieve all the relevant literature, the search string was not restricted by language or date of publication.

Reference lists of the selected studies were manually screened. Studies were included if they focused on prostate cancer or focused on active surveillance of patients with prostate cancer, and contained information on, or a reference, to an active surveillance guideline or a guideline on the management of prostate cancer in general that potentially includes recommendations on active surveillance. Studies that discussed active surveillance study protocols were excluded from the search. The literature search was followed by an electronic search of the individual websites of guideline collections, namely the National Guidelines Clearinghouse (www.guideline.gov) and Guidelines International Network (www.g-i-n.net) ${ }^{12}$. The following search string was used: 'active surveillance prostate cancer'/ 'watchful waiting prostate cancer'. For the Guidelines International Network database, a more general search string was used: 'prostate cancer'. Additionally, the internet was searched. For instance, websites of relevant organizations and specialties were examined. This process was repeated until August 2015 to check for recent updates and new guideline publications. Guidelines were included if they met the following inclusion criterion: the guideline contained recommendations on patient's eligibility for active surveillance or the type and/or frequency of monitoring during active surveillance, and/or criteria for switching from active surveillance to definitive therapy. Guidelines that did not fulfil this criterion, or were published before 2005, were excluded from our search. 


\begin{tabular}{|c|c|c|}
\hline $\begin{array}{l}\text { Country of } \\
\text { origin }\end{array}$ & Organization (abbreviation) & Title \\
\hline USA & American Urological Association (AUA) & $\begin{array}{l}\text { Guideline for the Management of Clinically } \\
\text { Localized Prostate Cancer: } 2007 \text { update }^{13}\end{array}$ \\
\hline USA & $\begin{array}{l}\text { The National Comprehensive Cancer } \\
\text { Network (NCCN) }\end{array}$ & $\begin{array}{l}\text { NCCN Guidelines version } 2.2014 \text { Prostate } \\
\text { Cancer }(2014)^{11}\end{array}$ \\
\hline Europe & European Association of Urology (EAU) & Guidelines on prostate cancer $(2014)^{14}$ \\
\hline UK & $\begin{array}{l}\text { National Institute for Health and Clinical } \\
\text { Excellence (NICE) }\end{array}$ & Prostate cancer: diagnosis and treatment $(2014)^{12}$ \\
\hline Germany & German Society of Urology (GSU) & $\begin{array}{l}\text { Interdisziplinäre Leitlinie der Qualität S3 zur } \\
\text { Früherkennung, Diagnose und Therapie der } \\
\text { verschiedenen Stadien des Prostatakarzinoms } \\
(2014)^{15}\end{array}$ \\
\hline $\begin{array}{l}\text { The } \\
\text { Netherlands }\end{array}$ & Dutch Urological Association (DUA) & Richtlijn prostaatcarcinoom $(2014)^{16}$ \\
\hline Belgium & $\begin{array}{l}\text { Belgian Healthcare Knowledge Centre } \\
\text { (KCE) }\end{array}$ & $\begin{array}{l}\text { A national clinical practice guideline on the } \\
\text { management of localised prostate cancer }(2013)^{17}\end{array}$ \\
\hline Finland & $\begin{array}{l}\text { The Finnish Medical Society Duodecim } \\
\text { (FCCG) }\end{array}$ & Prostate cancer (Eturauhassyöpä) $(2014)^{23}$ \\
\hline Scotland & $\begin{array}{l}\text { South East Scotland Cancer Network } \\
\text { (SCAN) }\end{array}$ & $\begin{array}{l}\text { SCAN Guideline for Active Surveillance } \\
\text { (Deferred Radical Treatment) of Early, Low- } \\
\text { Risk, Prostate Cancer (2009) }\end{array}$ \\
\hline Spain & Aragon Institute of Health Sciences (I+CS) & $\begin{array}{l}\text { Clinical Practice Guideline for Prostate Cancer } \\
\text { Treatment }(2008)^{19}\end{array}$ \\
\hline Canada & Cancer Care Nova Scotia (CCNS) & $\begin{array}{l}\text { Guidelines for the Management of } \\
\text { Prostate Cancer }(2006)^{10}\end{array}$ \\
\hline Canada & Alberta Health Services (AHS) & $\begin{array}{l}\text { Alberta Health Services Clinical Practice } \\
\text { Guideline: Prostate Cancer }(2014)^{20}\end{array}$ \\
\hline Canada & $\begin{array}{l}\text { Cancer Care Ontario (CCO) Program in } \\
\text { Evidence-Based Care (PEBC) }\end{array}$ & $\begin{array}{l}\text { Active Surveillance for the Management of } \\
\text { Localized Prostate Cancer: Guideline } \\
\text { Recommendations }(2015)^{24}\end{array}$ \\
\hline Singapore & National Cancer Centre Singapore (NCCS) & $\begin{array}{l}\text { Guidelines on Management of Prostate Cancer } \\
(2013)^{21}\end{array}$ \\
\hline New Zealand & Prostate Cancer Taskforce (PCT) & $\begin{array}{l}\text { Diagnosis and Management of Prostate Cancer in } \\
\text { New Zealand Men: Recommendations from the } \\
\text { Prostate Cancer Taskforce }(2012)^{22}\end{array}$ \\
\hline Australia & $\begin{array}{l}\text { Prostate Cancer Foundation of Australia } \\
\text { (PCFA) and Cancer Council Australia }\end{array}$ & $\begin{array}{l}\text { Draft clinical practice guidelines PSA Testing } \\
\text { and Early Management of Test-Detected Prostate } \\
\text { Cancer }(2015)^{25}\end{array}$ \\
\hline
\end{tabular}




\begin{tabular}{|c|c|c|c|c|c|c|c|c|c|}
\hline Guidelines & $\begin{array}{l}\text { Risk } \\
\text { category }\end{array}$ & $\begin{array}{l}\text { Clinical } \\
\text { stage }\end{array}$ & $\begin{array}{l}\text { Serum } \\
\text { PSA } \\
(\mathrm{ng} / \mathrm{ml})\end{array}$ & $\begin{array}{l}\text { Biopsy } \\
\text { Gleason } \\
\text { Score }\end{array}$ & $\begin{array}{l}\text { Serum } \\
\text { PSA } \\
\text { density } \\
(\mathrm{ng} / \mathrm{mL} / \mathrm{g})\end{array}$ & $\begin{array}{l}\text { Positive } \\
\text { cores } \\
(\mathrm{N})\end{array}$ & $\begin{array}{l}\text { Maximum } \\
\text { extent } \\
\text { cancer per } \\
\text { core }\end{array}$ & $\begin{array}{l}\text { Minimum } \\
\text { cores } \\
\text { sampled } \\
\text { (n) }\end{array}$ & Other \\
\hline \multirow[t]{3}{*}{$\mathrm{AUA}^{13}$} & Low & $\begin{array}{l}\text { T1c or } \\
\text { T2a }\end{array}$ & $\leq 10$ & $\leq 6$ & NR & NR & NR & NR & \\
\hline & Intermediate & $\mathrm{T} 2 \mathrm{~b}$ & $\begin{array}{l}>10- \\
20\end{array}$ & 7 & NR & NR & NR & NR & \\
\hline & High & $\mathrm{T} 2 \mathrm{c}$ & $>20$ & $8-10$ & NR & $\leq 2$ & $\leq 50 \%$ & 10 & \\
\hline $\mathrm{EAU}^{14}$ & Low & T1c-T2 & $\leq 10$ & $\leq 6$ & NR & $\leq 2$ & $\leq 50 \%$ & NR & \\
\hline \multirow[t]{2}{*}{$\mathrm{NCCN}^{11}$} & Very low & T1c & $<10$ & $\leq 6$ & $<0.15$ & $<3$ & $\leq 50 \%$ & NR & \\
\hline & Low & $\mathrm{T} 1-\mathrm{T} 2 \mathrm{a}$ & $<10$ & $\leq 6$ & NR & NR & NR & NR & \\
\hline \multirow[t]{2}{*}{$\mathrm{NICE}^{12}$} & Low & $\mathrm{T} 1-\mathrm{T} 2 \mathrm{a}$ & $<10$ & $\leq 6$ & NR & NR & NR & NR & \\
\hline & Intermediate & $\mathrm{T} 2 \mathrm{~b}$ & $10-20$ & 7 & NR & NR & NR & NR & \\
\hline $\mathrm{GSU}^{15}$ & Low & $\begin{array}{l}\text { T1c and } \\
\text { T2a }\end{array}$ & $\leq 10$ & $\leq 6$ & NR & $\leq 2$ & $\leq 50 \%$ & $10-12$ & \\
\hline \multirow[t]{3}{*}{$\mathrm{DUA}^{16}$} & Low & $\begin{array}{l}\text { T1c- } \\
\text { T2a }\end{array}$ & $<10$ & $<7$ & NR & 1 or 2 & NR & NR & \\
\hline & Intermediate & $\mathrm{T} 2 \mathrm{~b}-\mathrm{c}$ & $10-20$ & 7 & NR & NR & NR & NR & \\
\hline & High & T3 & $>20$ & $>7$ & NR & NR & NR & NR & \\
\hline $\mathrm{KCE}^{17}$ & Low & $\mathrm{T} 1-\mathrm{T} 2 \mathrm{a}$ & $<10$ & $<7$ & NR & NR & NR & NR & \\
\hline \multirow[t]{2}{*}{$\mathrm{FCCG}^{23}$} & Low & $\begin{array}{l}\text { T1a- } \\
\text { T2a }\end{array}$ & $<10$ & $<7$ & NR & $<3$ & NR & $10-12$ & \\
\hline & Intermediate & $\mathrm{T} 2 \mathrm{~b}$ & $10-20$ & $\leq 3+4$ & NR & $<3$ & NR & $10-12$ & \\
\hline SCAN $^{18}$ & Low & T1c & $<10$ & $\begin{array}{l}\leq 3+3, \\
\text { no } \\
\text { Grade } 4\end{array}$ & $<0.15$ & NR & $<50 \%$ & NR & $\begin{array}{l}<50 \% \text { of the } \\
\text { number of } \\
\text { biopsy cores } \\
\text { affected }\end{array}$ \\
\hline \multirow[t]{2}{*}{$\mathrm{CCNS}^{10}$} & Low & $\mathrm{T} 1-\mathrm{T} 2 \mathrm{a}$ & $<10$ & $\leq 6$ & NR & NR & NR & NR & \\
\hline & Intermediate & $\begin{array}{l}\text { T2b- } \\
\text { T2c }\end{array}$ & $10-19$ & 7 & NR & NR & NR & NR & \\
\hline $\mathrm{I}+\mathrm{CS}^{19}$ & Low & $\mathrm{T} 1-\mathrm{T} 2 \mathrm{a}$ & $\leq 10$ & $\leq 3+3$ & $\begin{array}{l}<0.15 \\
\mathrm{ng} / \mathrm{ml}\end{array}$ & NR & $<50 \%$ & $>10$ & \\
\hline $\mathrm{AHS}^{20}$ & Low & $<\mathrm{T} 2 \mathrm{~b}$ & $<10$ & $<7$ & NR & $\leq 3$ & $\leq 50 \%$ & 10 & \\
\hline $\mathrm{CCO}^{24}$ & Low & $\leq \mathrm{T} 2 \mathrm{a}$ & $<10$ & $\begin{array}{l}\leq 6 \text { or } \\
3+4=7 \\
\text { (for } \\
\text { selected } \\
\text { patients) }\end{array}$ & NR & NR & NR & NR & \\
\hline $\mathrm{NCCS}^{21}$ & Low & $\leq \mathrm{T} 2 \mathrm{a}$ & $<10$ & $\begin{array}{l}\leq 6 \text { (no } \\
\text { Gleason } \\
\text { grade } 4 \\
\text { or 5) }\end{array}$ & $<0.15$ & $<3$ & $\leq 50 \%$ & NR & \\
\hline \multirow[t]{2}{*}{$\mathrm{PCT}^{22}$} & Very low & T1a,T1c & $<10$ & 6 & $<0.15$ & $<3$ & $<50 \%$ & NR & \multirow[b]{2}{*}{$\begin{array}{l}\text { For men } \\
\text { younger than } \\
60 \text { years, a } \\
\text { more } \\
\text { conservative } \\
\text { approach } \\
\text { may be } \\
\text { warranted by } \\
\text { using the } \\
\text { more } \\
\text { restrictive } \\
\text { Epstein } \\
\text { criteria of } \\
\text { involvement: } \\
\text { less than } \\
\text { one-third of }\end{array}$} \\
\hline & Low & $\mathrm{T} 1-\mathrm{T} 2 \mathrm{a}$ & $<10$ & 6 & NR & NR & NR & NR & \\
\hline
\end{tabular}




\begin{tabular}{|c|c|c|c|c|c|c|c|c|c|}
\hline & & & & & & & & & $\begin{array}{l}\text { cores } \\
\text { affected, and } \\
\text { no more than } \\
50 \% \\
\text { involvement } \\
\text { of individual } \\
\text { cores } \\
\text { affected }\end{array}$ \\
\hline PCFA $^{25}$ & NR & T1-2 & $\leq 20$ & 6 & NR & NR & NR & NR & \\
\hline \multicolumn{10}{|c|}{$\begin{array}{l}\text { AUA, American Urological Association; AHS, Alberta Health Services; CCNS, Cancer Care Nova Scotia; CCO, Cancer Care } \\
\text { Ontario; DUA, Dutch Urological Association; EAU, European Association of Urology; FCCG, The Finnish Medical Society } \\
\text { Duodecim; GSU, German Society of Urology; I+CS, Aragon Institute of Health Sciences; KCE, Belgian Healthcare Knowledge } \\
\text { Centre; NICE, National Institute for Health and Clinical Excellence; NCCN, The National Comprehensive Cancer Network; } \\
\text { NCCS, National Cancer Centre Singapore; NR, not reported; PEBC, Program in Evidence-Based Care; PCFA, Prostate Cancer } \\
\text { Foundation of Australia, PCT; Prostate Cancer Taskforce; SCAN, South East Scotland Cancer Network. }\end{array}$} \\
\hline
\end{tabular}




\begin{tabular}{|c|c|c|c|c|c|c|}
\hline Guidelines & $\begin{array}{l}\text { Risk } \\
\text { category }\end{array}$ & Age & $\begin{array}{l}\text { Life } \\
\text { expectancy } \\
\text { (years) }\end{array}$ & $\begin{array}{l}\text { Presence of } \\
\text { comorbidities/ } \\
\text { general health } \\
\text { condition }\end{array}$ & $\begin{array}{l}\text { Patient } \\
\text { preferences }\end{array}$ & Other \\
\hline \multirow[t]{3}{*}{$\mathrm{AUA}^{13}$} & Low & NR & NR & Mentioned & Mentioned & - \\
\hline & Intermediate & NR & NR & Mentioned & Mentioned & - \\
\hline & High & NR & NR & NR & NR & - \\
\hline EAU $^{14}$ & Low & NR & $>10$ & NR & NR & - \\
\hline \multirow[t]{2}{*}{$\mathrm{NCCN}^{11}$} & Very low & NR & $>10$ & NR & NR & - \\
\hline & Low & NR & $>10$ & NR & NR & - \\
\hline \multirow[t]{2}{*}{$\mathrm{NICE}^{12}$} & Low & NR & NR & NR & Mentioned & - \\
\hline & Intermediate & NR & NR & NR & Mentioned & - \\
\hline $\mathrm{GSU}^{15}$ & Low & NR & NR & NR & NR & - \\
\hline \multirow[t]{3}{*}{$\mathrm{DUA}^{16}$} & Low & NR & NR & NR & NR & - \\
\hline & Intermediate & Mentioned & Mentioned & Mentioned & NR & - \\
\hline & High & Mentioned & Mentioned & Mentioned & NR & - \\
\hline $\mathrm{KCE}^{17}$ & Low & NR & $>10$ & NR & Mentioned & - \\
\hline \multirow{2}{*}{$\mathrm{FCCG}^{23}$} & Low & Mentioned & Mentioned & Mentioned & Mentioned & - \\
\hline & Intermediate & Mentioned & Mentioned & Mentioned & Mentioned & - \\
\hline $\mathrm{SCAN}^{18}$ & Low & $\leq 75$ & $\begin{array}{l}>10 \text { (with } \\
\text { caution in } \\
\text { those with } \\
\text { LE of }>20 \text { ) }\end{array}$ & NR & NR & \\
\hline \multirow[t]{2}{*}{$\mathrm{CCNS}^{10}$} & Low & NR & NR & NR & NR & - \\
\hline & Intermediate & NR & NR & NR & NR & - \\
\hline $\mathrm{I}+\mathrm{CS}^{19}$ & Low & NR & NR & Mentioned & Mentioned & - \\
\hline $\mathrm{AHS}^{20}$ & Low & NR & NR & NR & Mentioned & - \\
\hline $\mathrm{CCO}^{24}$ & Low & NR & NR & NR & NR & - \\
\hline $\mathrm{NCCS}^{21}$ & Low & NR & $<10$ & Mentioned & Mentioned & - \\
\hline \multirow[t]{2}{*}{$\mathrm{PCT}^{22}$} & Very low & NR & Mentioned & Mentioned & Mentioned & \multirow[b]{2}{*}{$\begin{array}{l}\text { Ultimately a recommendation for } \\
\text { AS must be based on careful, } \\
\text { individualised weighing of a } \\
\text { number of factors: life } \\
\text { expectancy, disease } \\
\text { characteristics, general health } \\
\text { condition, potential side effects } \\
\text { of treatment, and patient } \\
\text { preference. }\end{array}$} \\
\hline & Low & NR & Mentioned & Mentioned & Mentioned & \\
\hline PCFA & NR & NR & NR & NR & NR & - \\
\hline \multicolumn{7}{|c|}{$\begin{array}{l}\text { AHS, Alberta Health Services; AUA, American Urological Association; CCNS, Cancer Care Nova Scotia; CCO, Cancer Care } \\
\text { Ontario; DUA, Dutch Urological Association; EAU, European Association of Urology; FCCG, The Finnish Medical Society } \\
\text { Duodecim; GSU, German Society of Urology; I+CS, Aragon Institute of Health Sciences; KCE, Belgian Healthcare Knowledge } \\
\text { Centre; NCCN, The National Comprehensive Cancer Network; NCCS, National Cancer Centre Singapore; NICE, National } \\
\text { Institute for Health and Clinical Excellence; NR, not reported; PCFA, Prostate Cancer Foundation of Australia, PCT; Prostate } \\
\text { Cancer Taskforce; PEBC, Program in Evidence-Based Care; SCAN, South East Scotland Cancer Network. }\end{array}$} \\
\hline
\end{tabular}




\begin{tabular}{|c|c|c|c|c|c|}
\hline $\begin{array}{l}\text { Guidelin } \\
\text { es }\end{array}$ & serum PSA & $\begin{array}{l}\text { PSA kinetics } \\
\text { (PSADT, PSAV) }\end{array}$ & DRE & Rebiopsy & mpMRI \\
\hline $\mathrm{AUA}^{13 *}$ & NR & NR & NR & NR & NR \\
\hline $\mathrm{EAU}^{14}$ & Mentioned & NR & Mentioned & Mentioned & NR \\
\hline $\mathrm{NCCN}^{11 \%}$ & $\begin{array}{l}\geq 6 \text {-monthly } \\
\text { intervals unless } \\
\text { clinically } \\
\text { indicated }\end{array}$ & NR & $\begin{array}{l}\geq 12 \text {-monthly } \\
\text { intervals } \\
\text { unless } \\
\text { clinically } \\
\text { indicated }\end{array}$ & $\begin{array}{l}\leq 12 \text {-monthly intervals } \\
\text { unless clinically } \\
\text { indicated, 6-monthly } \\
\text { intervals if initial biopsy } \\
<10 \text { cores. }\end{array}$ & $\begin{array}{l}\text { To be considered if serum } \\
\text { PSA rises and biopsy } \\
\text { samples are negative }\end{array}$ \\
\hline $\mathrm{NICE}^{12}$ & $\begin{array}{l}\text { Year 1: Every } \\
3-4 \text { months, } \\
\text { year 2-4: 3-6 } \\
\text { months } \\
\text { Year 5+: } 6 \\
\text { months }\end{array}$ & $\begin{array}{l}\text { Measured } \\
\text { throughout } \\
\text { surveillance. Can } \\
\text { include doubling } \\
\text { time and velocity }\end{array}$ & $\begin{array}{l}\text { Year 1: 6-12 } \\
\text { months, year } \\
2-4: 6-12 \\
\text { months, } \\
\text { year 5+: } \\
\text { annually }\end{array}$ & $\begin{array}{l}\text { Year 1: } 12 \text { months, or if } \\
\text { concerned about clinical } \\
\text { or serum PSA changes }\end{array}$ & $\begin{array}{l}\text { At enrollment if not done } \\
\text { before, if concern exists } \\
\text { about clinical or PSA } \\
\text { changes }\end{array}$ \\
\hline $\mathrm{GSU}^{15}$ & $\begin{array}{l}\text { Year 0-2: every } \\
3 \text { months, if } \\
\text { serum PSA is } \\
\text { stable then } \\
\text { every } 6 \text { months }\end{array}$ & Mentioned & $\begin{array}{l}\text { Year } 0-2: \\
\text { every } 3 \\
\text { months, if } \\
\text { serum PSA is } \\
\text { stable then } \\
\text { every } 6 \\
\text { months }\end{array}$ & $\begin{array}{l}\text { Year 0-3: every 12-18 } \\
\text { months, then every } 3 \\
\text { years }\end{array}$ & NR \\
\hline $\mathrm{DUA}^{16 *}$ & NR & NR & NR & NR & NR \\
\hline $\mathrm{KCE}^{17}$ & Every 6 months & NR & $\begin{array}{l}\text { Every } 6 \\
\text { months }\end{array}$ & $\begin{array}{l}\text { Within } 1 \text { year, after this } \\
\text { biopsy repeat biopsies } \\
\text { (timing can currently not } \\
\text { be defined) }\end{array}$ & $\begin{array}{l}\text { Imaging every year can be } \\
\text { considered }\end{array}$ \\
\hline $\mathrm{FCCG}^{23 \S}$ & NR & NR & NR & NR & NR \\
\hline SCAN $^{18}$ & $\begin{array}{l}\text { Year 1: 3- } \\
\text { monthly } \\
\text { intervals after } \\
\text { first year, 6- } \\
\text { monthly if } \\
\text { stable }\end{array}$ & $\begin{array}{l}\text { PSA doubling time } \\
\text { after } 5 \text { PSA } \\
\text { measurements }\end{array}$ & $\begin{array}{l}\text { Minimum } \\
\text { every } 6 \\
\text { months }\end{array}$ & $\begin{array}{l}\text { Within } 6 \text { months then at } \\
1,4,7 \text { and } 10 \text { years }\end{array}$ & NR \\
\hline $\mathrm{CCNS}^{10}$ & 6-monthly & NR & 6-monthly & $\begin{array}{l}\text { At } 6 \text { months if original } \\
\text { biopsy }<10 \text { cores or } \\
\text { discordant with clinical } \\
\text { findings, otherwise within } \\
18 \text { months, and then } \\
\text { periodically }\end{array}$ & NR \\
\hline $\mathrm{I}+\mathrm{CS}^{19}$ & $\begin{array}{l}\text { Every } 3 \text { months } \\
\text { for first } 2 \text { years, } \\
\text { then every } 6 \\
\text { months }\end{array}$ & $\begin{array}{l}\text { Estimation of PSA } \\
\text { speed with linear } \\
\text { regression, using at } \\
\text { least } 5 \text { PSA } \\
\text { determinations } \\
\text { extended over at } \\
\text { least a year }\end{array}$ & $\begin{array}{l}\text { Every } 3 \\
\text { months for } \\
\text { first } 2 \text { years, } \\
\text { then every } 6 \\
\text { months }\end{array}$ & $\begin{array}{l}\text { After } 1 \text { year, } 4 \text { years, } 7 \\
\text { years (minimum } 10 \text { cores } \\
\text { per biopsy) }\end{array}$ & NR \\
\hline $\mathrm{AHS}^{20}$ & $\begin{array}{l}\text { PSA every 3-6 } \\
\text { months, at the } \\
\text { physician's } \\
\text { discretion }\end{array}$ & Mentioned & $\begin{array}{l}\text { DRE } \\
\text { annually, at } \\
\text { the } \\
\text { physician's } \\
\text { discretion }\end{array}$ & $\begin{array}{l}\text { Repeat biopsies 1-2 years } \\
\text { after initial diagnosis, } \\
\text { further biopsies every } 2-3 \\
\text { years or as clinically } \\
\text { indicated }\end{array}$ & NR \\
\hline $\mathrm{CCO}^{24 \|}$ & $\begin{array}{l}\text { Every 3-6 } \\
\text { months }\end{array}$ & NR & Annually & $\begin{array}{l}\text { 12-14-core confirmatory } \\
\text { TRUS biopsy (including } \\
\text { anterior directed cores) } \\
\text { within 6-12 months, then } \\
\text { serial biopsy a minimum } \\
\text { of every } 3-5 \text { years }\end{array}$ & $\begin{array}{l}\text { Indicated when a patient's } \\
\text { clinical findings are } \\
\text { discordant with pathological } \\
\text { findings, and for identifying } \\
\text { occult cancers or changes } \\
\text { indicative of tumour }\end{array}$ \\
\hline
\end{tabular}




\begin{tabular}{|l|l|l|l|l|l|}
\hline & & & & thereafter & $\begin{array}{l}\text { progression in patients at } \\
\text { risk }\end{array}$ \\
\hline NCCS $^{21}$ & $3-6$ monthly & NR & Annually & $\begin{array}{l}\text { Within the first 12-18 } \\
\text { months, or if no adverse } \\
\text { features after 2 years, } \\
\text { interval between follow- } \\
\text { up consultations and } \\
\text { repeat biopsies can be } \\
\text { increased }\end{array}$ & NR \\
\hline PCT $^{22}$ & $\begin{array}{l}\text { 6-monthly, or 3- } \\
\text { monthly if } \\
\text { concerned about } \\
\text { progression }\end{array}$ & Mentioned & Mentioned & $\begin{array}{l}\text { Within 12 months of } \\
\text { initial biopsy, or as } \\
\text { clinically indicated }\end{array}$ & NR \\
\hline PCFA & NR & NR & NR & NR & NR \\
\hline
\end{tabular}

*Guidelines contain no follow-up recommendations. ${ }^{+}$More rigorous follow up recommended in younger than in older men. ${ }^{\S}$ Use of 'proper' diagnostics emphasized. "Daily 5- $\alpha$ reductase inhibitors might have a role in men on active surveillance. AHS, Alberta Health Services; AUA, American Urological Association; CCNS, Cancer Care Nova Scotia; CCO, Cancer Care Ontario; DUA, Dutch Urological Association; EAU, European Association of Urology; FCCG, The Finnish Medical Society Duodecim; GSU, German Society of Urology; I+CS, Aragon Institute of Health Sciences; KCE, Belgian Healthcare Knowledge Centre; mpMRI, multiparametric MRI; NCCN, The National Comprehensive Cancer Network; NCCS, National Cancer Centre Singapore; NICE, National Institute for Health and Clinical Excellence; NR, not reported; PCFA, Prostate Cancer Foundation of Australia, PCT; Prostate Cancer Taskforce; PEBC, Program in Evidence-Based Care; PSADT, PSA doubling time; PSAV, PSA velocity; SCAN, South East Scotland Cancer Network. 


\begin{tabular}{|c|c|c|c|c|c|c|c|c|}
\hline Guidelines & $\begin{array}{l}\text { serum } \\
\text { PSA } \\
\text { (ng/m } \\
\text { l) }\end{array}$ & $\begin{array}{l}\text { PSA } \\
\text { kinetics } \\
\text { (PSADT, } \\
\text { PSAV) }\end{array}$ & DRE & Imaging & $\begin{array}{l}\text { Rebiopsy } \\
\text { Gleason Score }\end{array}$ & $\begin{array}{l}\text { Tumour } \\
\text {-positive } \\
\text { cores } \\
\text { (N) }\end{array}$ & $\begin{array}{l}\text { Cancer } \\
\text { per } \\
\text { core }\end{array}$ & General \\
\hline $\mathrm{AUA}^{13} *$ & NR & NR & NR & NR & NR & NR & NR & NR \\
\hline $\mathrm{EAU}^{14} *$ & NR & NR & NR & NR & NR & NR & NR & NR \\
\hline $\mathrm{NCCN}^{11}$ & NR & NR & NR & NR & $4 / 5$ & $\begin{array}{l}\text { Increase } \\
\text { in } \\
\text { number }\end{array}$ & $\begin{array}{l}\text { Increase } \\
\text { in } \\
\text { extent } \\
\text { per core }\end{array}$ & NR \\
\hline $\mathrm{NICE}^{12 \dagger}$ & NR & NR & NR & NR & NR & NR & NR & $\begin{array}{l}\text { Disease } \\
\text { progression }\end{array}$ \\
\hline $\mathrm{GSU}^{15}$ & $>10$ & $\begin{array}{l}\text { PSADT }<3 \\
\text { yrs }\end{array}$ & $>c T 2 a$ & NR & $>6$ & $>2$ & $>50 \%$ & NR \\
\hline $\operatorname{DUA}^{16 *}$ & NR & NR & NR & NR & NR & NR & NR & NR \\
\hline $\mathrm{KCE}^{17}$ & $>10$ & $\begin{array}{l}\text { PSADT }<3 \\
\text { years }\end{array}$ & $\begin{array}{l}\text { Clinical } \\
\text { change }\end{array}$ & $\begin{array}{l}\text { Suspiciou } \\
\text { s lesions } \\
\text { detected }\end{array}$ & NR & NR & NR & NR \\
\hline $\mathrm{FCCG}^{23}$ & NR & $\begin{array}{l}\text { PSADT }<3 \\
\text { years }\end{array}$ & NR & NR & $>6$ & $>2$ & NR & $\begin{array}{l}\text { If reclassified } \\
\text { to clinically } \\
\text { relevant }\end{array}$ \\
\hline SCAN $^{18 \S}$ & NR & $\begin{array}{l}\text { PSADT } \\
\text { time }<3 \\
\text { years. }\end{array}$ & $\begin{array}{l}\text { Progression of } \\
\text { palpable } \mathrm{T} 2 \\
\text { disease on } \\
\text { DRE or } \\
\text { palpable } \\
\text { lesions } \\
\text { appearing. }\end{array}$ & NR & 4 or 5 & NR & $\begin{array}{l}>50 \% \\
\text { of any } \\
\text { core, } \\
>50 \% \\
\text { of cores } \\
\text { affected }\end{array}$ & NR \\
\hline $\mathrm{CCNS}^{10}$ & NR & NR & NR & NR & NR & NR & NR & $\begin{array}{l}\text { Disease } \\
\text { progression }\end{array}$ \\
\hline $\mathrm{I}+\mathrm{CS}^{1919}$ & NR & $\begin{array}{l}\text { PSA } \\
\text { velocity } \\
>1 \mathrm{ng} / \mathrm{ml} \text { per } \\
\text { year }\end{array}$ & Mentioned & NR & Mentioned & NR & NR & NR \\
\hline $\mathrm{AHS}^{20 \|}$ & NR & $\begin{array}{l}\text { PSADT <3 } \\
\text { years }\end{array}$ & $\begin{array}{l}\text { Increase in } \\
\text { clinical stage } \\
\text { from baseline } \\
\text { status }\end{array}$ & NR & $\begin{array}{l}\text { Presence of } \\
\text { pattern } \geq 4\end{array}$ & NR & $>50 \%$ & NR \\
\hline $\mathrm{CCO}^{24}$ & NR & NR & NR & NR & $\begin{array}{l}\text { Gleason } \geq 7(4+3 \\
\text { or } 3+4 \text { with } \\
\text { Gleason pattern } 4 \\
\text { pathology } \\
\text { accounting for } \\
>10 \% \text { total } \\
\text { tumour) or } 3+ \\
\text { and/or significant } \\
\text { increases in the } \\
\text { volume of } \\
\text { Gleason } 6 \text { tumour }\end{array}$ & NR & NR & NR \\
\hline $\mathrm{NCCS}^{21 \|}$ & NR & NR & $\begin{array}{l}\text { Abnormal, or } \\
\text { change } \\
\text { observed on } \\
\text { DRE }\end{array}$ & NR & $\begin{array}{l}\text { Increase in } \\
\text { Gleason score } \geq 7 \\
\text { or any Gleason } \\
\text { pattern } 4 \text { or } 5\end{array}$ & $>2$ & $>50 \%$ & NR \\
\hline $\mathrm{PCT}^{22} *$ & NR & NR & NR & NR & NR & NR & NR & NR \\
\hline $\mathrm{PCFA}^{25 *}$ & NR & NR & NR & NR & NR & NR & NR & NR \\
\hline \multicolumn{9}{|c|}{$\begin{array}{l}\text { *Guidelines contain no recommendations for switching from active surveillance to definitive therapy. }{ }^{*} \text { Guidelines recommend } \\
\text { consideration of personal preferences, comorbidities and life expectancy }{ }^{\S} \text { Presence of bilateral disease is considered an appropriate } \\
\text { criterion for switching to definitive therapy }{ }^{\|} \text {Guidelines recommend consideration of personal preferences. AHS, Alberta Health } \\
\text { Services; AUA, American Urological Association; CCNS, Cancer Care Nova Scotia; CCO, Cancer Care Ontario; DUA. Dutch }\end{array}$} \\
\hline
\end{tabular}


Urological Association; EAU, European Association of Urology; FCCG, The Finnish Medical Society Duodecim; GSU, German Society of Urology; I+CS, Aragon Institute of Health Sciences; KCE, Belgian Healthcare Knowledge Centre; NCCN, The National Comprehensive Cancer Network; NCCS, National Cancer Centre Singapore; NICE, National Institute for Health and Clinical

Excellence; NR, not reported; PCFA, Prostate Cancer Foundation of Australia, PCT; Prostate Cancer Taskforce; PEBC, Program in Evidence-Based Care; PSADT, PSA doubling time; PSAV, PSA velocity; SCAN, South East Scotland Cancer Network. 


\begin{tabular}{|c|c|c|c|c|c|}
\hline $\begin{array}{l}\text { Guide } \\
\text { lines }\end{array}$ & $\begin{array}{l}\text { Risk } \\
\text { cate } \\
\text { gory }\end{array}$ & Tumour characteristics & $\begin{array}{l}\text { Patient } \\
\text { characte } \\
\text { ristics }\end{array}$ & Follow-up monitoring & $\begin{array}{l}\text { Criteria for switching from active } \\
\text { surveillance to definitive therapy }\end{array}$ \\
\hline \multirow[t]{3}{*}{$\mathrm{AUA}_{3}{ }^{1}$} & Low & $\begin{array}{l}\text { Tumour stage T1c or T2a, } \\
\text { serum PSA } \leq 10 \mathrm{ng} / \mathrm{ml}, \\
\text { biopsy Gleason score } \leq 6\end{array}$ & NR & \multirow[t]{3}{*}{ NR } & \multirow[t]{3}{*}{ NR } \\
\hline & $\begin{array}{l}\text { Inter } \\
\text { medi } \\
\text { ate }\end{array}$ & $\begin{array}{l}\text { Tumour stage T2b, serum } \\
\text { PSA }>10-20 \mathrm{ng} / \mathrm{ml} \text {, biopsy } \\
\text { Gleason score of } 7\end{array}$ & NR & & \\
\hline & High & $\begin{array}{l}\text { Tumour stage T2c, serum } \\
\text { PSA }>20 \mathrm{ng} / \mathrm{ml}, 8-10 \\
\text { ng/ml, } \leq 2 \text { tumour-positive } \\
\text { biopsy core samples, } \leq 50 \% \\
\text { of tumour positivity per } \\
\text { biopsy core, } 10 \text { cores } \\
\text { sampled }\end{array}$ & NR & & \\
\hline$\underset{4}{\text { EAU }^{1}}$ & Low & $\begin{array}{l}\text { Tumour stage } \mathrm{T} 1 \mathrm{c}-\mathrm{T} 2, \\
\text { serum PSA } \leq 10 \mathrm{ng} / \mathrm{ml}, \\
\text { biopsy Gleason score } \leq 6, \\
\leq 2 \text { tumour-positive biopsy } \\
\text { core samples, } \leq 50 \% \\
\text { tumour positivity per } \\
\text { biopsy core }\end{array}$ & $\begin{array}{l}\mathrm{LE}>10 \\
\text { years }\end{array}$ & $\begin{array}{l}\text { Serum PSA, DRE and rebiopsy all } \\
\text { mentioned }\end{array}$ & NR \\
\hline \multirow[t]{2}{*}{$\begin{array}{l}\mathrm{NCC} \\
\mathrm{N}^{11}\end{array}$} & $\begin{array}{l}\text { Very } \\
\text { low }\end{array}$ & $\begin{array}{l}\text { Tumour stage T1c, serum } \\
\text { PSA }<10 \mathrm{ng} / \mathrm{ml}, \text { biopsy } \\
\text { Gleason score } \leq 6, \text { PSA } \\
\text { density }<0.15,<3 \text { tumour- } \\
\text { positive biopsy core } \\
\text { samples, } \leq 50 \% \text { tumour } \\
\text { positivity per biopsy core }\end{array}$ & LE > 10 & \multirow[t]{2}{*}{$\begin{array}{l}\text { Serum PSA } \leq 6 \text {-monthly unless } \\
\text { clinically indicated, DRE } \leq 12- \\
\text { monthly unless clinically indicated, } \\
\text { rebiopsy } \leq 12 \text {-monthly unless } \\
\text { clinically indicated or at } 6 \text { months } \\
\text { if the initial biopsy sample had }<10 \\
\text { cores, MRI mentioned }\end{array}$} & \multirow[t]{2}{*}{$\begin{array}{l}\text { Rebiopsy sample Gleason score } \\
\text { contains } 4 \text { or } 5 \text { grade disease, } \\
\text { increased number of tumour- } \\
\text { positive cores or increased extent } \\
\text { of cancer per core }\end{array}$} \\
\hline & Low & $\begin{array}{l}\text { Tumour stage T1-T2a, } \\
\text { serum PSA }<10 \mathrm{ng} / \mathrm{ml}, \\
\text { biopsy Gleason score } \leq 6\end{array}$ & $\mathrm{LE}>10$ & & \\
\hline \multirow[t]{2}{*}{$\begin{array}{l}\text { NICE } \\
12\end{array}$} & Low & $\begin{array}{l}\text { Tumour stage T1-T2a, } \\
\text { serum PSA }<10 \mathrm{ng} / \mathrm{ml}, \\
\text { biopsy Gleason score } \leq 6\end{array}$ & NR & \multirow[b]{2}{*}{$\begin{array}{l}\text { Serum PSA every } 3-4 \text { months } 1 \\
\text { year post-diagnosis, every } 3-6 \\
\text { months } 2-4 \text { years post-diagnosis, } \\
\text { and thenevery } 6 \text { months post- } \\
\text { diagnosis, PSA kinetics (PSADT } \\
\text { and PSAV) to be measured } \\
\text { throughout active surveillance, } \\
\text { DRE every 6-12-months } 1-4 \text { years } \\
\text { post-diagnosis, and then annually } \\
\text { thereafter, rebiopsy sampling } 12 \\
\text { months after diagnosis or if } \\
\text { concerns exist about clinical or } \\
\text { serum PSA changes, MRI at } \\
\text { enrollment if not done before or in } \\
\text { the presence of concern about } \\
\text { clinical or PSA changes }\end{array}$} & \multirow{2}{*}{$\begin{array}{l}\text { Switching recommended if disease } \\
\text { progression observed, also taking } \\
\text { into account the patient's life } \\
\text { expectancy, treatment preferences } \\
\text { and comorbidities }\end{array}$} \\
\hline & $\begin{array}{l}\text { Inter } \\
\text { medi } \\
\text { ate }\end{array}$ & $\begin{array}{l}\text { Tumour stage T2b, serum } \\
\text { PSA } 10-20 \mathrm{ng} / \mathrm{ml} \text {, biopsy } \\
\text { Gleason score of } 7\end{array}$ & NR & & \\
\hline $\mathrm{GSU}_{5}^{1}$ & Low & $\begin{array}{l}\text { Tumour stage T1c-T2a, } \\
\text { serum PSA } \leq 10 \mathrm{ng} / \mathrm{ml} \text {, } \\
\text { biopsy Gleason score } \leq 6 \text {, } \\
\leq 2 \text { tumour positive biopsy } \\
\text { core samples, } \leq 50 \% \\
\text { tumour positivity per } \\
\text { biopsy core, } 10-12 \text { cores } \\
\text { sampled }\end{array}$ & NR & $\begin{array}{l}\text { Serum PSA every } 3 \text { months } 0-2 \\
\text { years post-diagnosis, every } 6 \\
\text { months thereafter if levels remain } \\
\text { stable, PSA kinetics mentioned, } \\
\text { DRE every } 3 \text { months } 0-2 \text { years } \\
\text { post-diagnosis then every } 6 \text { months } \\
\text { thereafter, if PSA stable, } \\
\text { rebiopsy every } 12-18 \text { months } \\
\text { within } 3 \text { years post-diagnosis, then } \\
\text { every } 3 \text { years thereafter }\end{array}$ & $\begin{array}{l}\text { Switching recommended if serum } \\
\text { PSA }>10 \text { ng/ml, PSADT }<3 \text { years, } \\
\text { tumour stage }>\text { cT2a, rebiopsy } \\
\text { Gleason score }>6,>2 \text { tumour- } \\
\text { positive biopsy sample cores, } \\
>50 \% \text { cancer per biopsy sample } \\
\text { core }\end{array}$ \\
\hline
\end{tabular}




\begin{tabular}{|c|c|c|c|c|c|}
\hline $\mathrm{DUA}_{6}^{1}$ & Low & $\begin{array}{l}\text { Tumour stage T1c-T2a, } \\
\text { serum PSA }<10 \mathrm{ng} / \mathrm{ml}, \\
\text { biopsy Gleason score }<7,1 \\
\text { or } 2 \text { tumour-positive } \\
\text { biopsy core samples } \\
\end{array}$ & NR & \multirow[t]{3}{*}{ NR } & \multirow[t]{3}{*}{ NR } \\
\hline & $\begin{array}{l}\text { Inter } \\
\mathrm{m}\end{array}$ & $\begin{array}{l}\text { Tumour stage T2b-c, } \\
\text { serum PSA } 10-20 \mathrm{ng} / \mathrm{ml} \text {, } \\
\text { biopsy Gleason score of } 7\end{array}$ & $\begin{array}{l}\text { mention } \\
\text { ed }\end{array}$ & & \\
\hline & High & $\begin{array}{l}\text { Tumour stage T3, serum } \\
\text { PSA }>20 \mathrm{ng} / \mathrm{ml} \text {, biopsy } \\
\text { Gleason score of }>7\end{array}$ & $\begin{array}{l}\text { Age and } \\
\text { LE } \\
\text { mention } \\
\text { ed }\end{array}$ & & \\
\hline $\mathrm{KCE}_{7}^{1}$ & Low & $\begin{array}{l}\text { Tumour stage T1-T2a, } \\
\text { serum PSA }<10 \mathrm{ng} / \mathrm{ml} \text {, } \\
\text { Gleason score of }<7\end{array}$ & $\mathrm{LE}>10$ & $\begin{array}{l}\text { Serum PSA every } 6 \text { months, DRE } \\
\text { every } 6 \text { months, } \\
\text { rebiopsy within } 1 \text {-year and repeated } \\
\text { thereafter (timing can currently not } \\
\text { be defined), annual MRI }\end{array}$ & $\begin{array}{l}\text { Switching recommended if serum } \\
\text { PSA }>10 \text { ng/ml, PSADT }<3 \text { years, } \\
\text { clinical change detected during } \\
\text { DRE, or if suspicious lesions } \\
\text { observed during imaging }\end{array}$ \\
\hline \multirow[t]{2}{*}{$\begin{array}{l}\mathrm{FCC} \\
\mathrm{G}^{23}\end{array}$} & Low & $\begin{array}{l}\text { Tumour stage T1a-T2a, } \\
\text { serum PSA }<10 \mathrm{ng} / \mathrm{ml}, \\
\text { Gleason score }<7,<3 \\
\text { tumour-positive biopsy } \\
\text { core samples, } 10-12 \text { cores } \\
\text { sampled }\end{array}$ & $\begin{array}{l}\text { Mention } \\
\text { ed }\end{array}$ & \multirow[t]{2}{*}{$\begin{array}{l}\text { Serum PSA, PSA kinetics, DRE } \\
\text { and rebiopsy all mentioned }\end{array}$} & \multirow[t]{2}{*}{$\begin{array}{l}\text { Switching recommended if PSADT } \\
<3 \text { years, rebiopsy Gleason score } \\
>6,>2 \text { tumour-positive biopsy } \\
\text { sample cores are detected, or if } \\
\text { disease is reclassified as being } \\
\text { clinically relevant }\end{array}$} \\
\hline & $\begin{array}{l}\text { Inter } \\
\mathrm{m}\end{array}$ & $\begin{array}{l}\text { Tumour stage T2b, serum } \\
\text { PSA } 10-20 \mathrm{ng} / \mathrm{ml}, \text { biopsy } \\
\text { Gleason score of } \leq 3+4,<3 \\
\text { tumour-positive biopsy } \\
\text { core samples, } 10-12 \text { cores } \\
\text { sampled }\end{array}$ & $\begin{array}{l}\text { Age and } \\
\text { LE } \\
\text { mention } \\
\text { ed }\end{array}$ & & \\
\hline $\begin{array}{l}\text { SCA } \\
\mathrm{N}^{18}\end{array}$ & Low & $\begin{array}{l}\text { Tumour stage T1c, serum } \\
\text { PSA }<10 \mathrm{ng} / \mathrm{ml}, \text { biopsy } \\
\text { Gleason score of } \leq 3+3 \text {, no } \\
\text { Grade } 4 \text {, PSA density } \\
<0.15,<50 \% \text { tumour } \\
\text { positivity per biopsy core, } \\
<50 \% \text { of the number of } \\
\text { biopsy cores affected }\end{array}$ & $\begin{array}{l}\text { Age } \leq 75 \\
\mathrm{LE}>10\end{array}$ & $\begin{array}{l}\text { Serum PSA every } 3 \text { months within } \\
1 \text { year post-diagnosis, } 6 \text {-monthly } \\
\text { sampling thereafter if stable, } \\
\text { PSADT to be measured after } 5 \text { PSA } \\
\text { results, } \leq 6 \text { monthly DRE, rebiopsy } \\
\text { within } 6 \text {-months post-diagnosis } \\
\text { then at } 1,4,7 \text { and } 10 \text { years }\end{array}$ & $\begin{array}{l}\text { Switching recommended if: } \\
\text { PSADT <3 years, progression of } \\
\text { palpable T2-stage disease on DRE } \\
\text { or palpable lesions appearing, } \\
\text { emergence of Gleason grade } \\
\text { pattern } 4 \text { or } 5,>50 \% \text { spread of } \\
\text { cancer in any biopsy core sample, } \\
>50 \% \text { of core samples affected, or } \\
\text { if disease is bilateral }\end{array}$ \\
\hline \multirow[t]{2}{*}{$\begin{array}{l}\mathrm{CCN} \\
\mathrm{S}^{10}\end{array}$} & Low & $\begin{array}{l}\text { Tumour stage T1-T2a, } \\
\text { serum PSA }<10 \mathrm{ng} / \mathrm{ml}, \\
\text { biopsy Gleason score of } \leq 6\end{array}$ & NR & \multirow{2}{*}{$\begin{array}{l}\text { Serum PSA every } 6 \text { months, DRE } \\
\text { every } 6 \text { months, rebiopsy at } 6 \\
\text { months if original biopsy sample } \\
\text { had }<10 \text { cores or findings are } \\
\text { discordant with clinical findings, } \\
\text { within } 18 \text { months otherwise then } \\
\text { periodically thereafter }\end{array}$} & \multirow[t]{2}{*}{$\begin{array}{l}\text { Switching recommended if disease } \\
\text { progression observed }\end{array}$} \\
\hline & $\begin{array}{l}\text { Inter } \\
\text { medi } \\
\text { ate }\end{array}$ & $\begin{array}{l}\text { Tumour stage T2b-T2c, } \\
\text { serum PSA } 10-19 \mathrm{~g} / \mathrm{ml} \text {, } \\
\text { biopsy Gleason score of } 7\end{array}$ & NR & & \\
\hline${ }_{9}^{\mathrm{I}+\mathrm{CS}^{1}}$ & Low & $\begin{array}{l}\text { Tumour stage } \mathrm{T} 1-\mathrm{T} 2 \mathrm{a}, \\
\text { serum PSA } \leq 10 \mathrm{ng} / \mathrm{ml} \\
\text { biopsy Gleason score of } \\
\leq 3+3, \text { serum PSA density } \\
\text { of }<0.15 \mathrm{ng} / \mathrm{ml},<50 \% \\
\text { tumour positivity per } \\
\text { biopsy core, }>10 \text { cores } \\
\text { sampled }\end{array}$ & NR & $\begin{array}{l}\text { Serum PSA Every } 3 \text { months within } \\
0-2 \text { years post-diagnosis, then 6- } \\
\text { monthly thereafter,"Estimation of } \\
\text { PSA speed with linear regression, } \\
\text { using at least } 5 \text { PSA determinations } \\
\text { extended over at least a year", DRE } \\
\text { every } 3 \text { months within } 0-2 \text { years } \\
\text { post-diagnosis then } 6 \text {-monthly } \\
\text { thereafter, Rebiopsy sampling after } \\
1 \text { year, } 4 \text { years and } 7 \text { years } \\
\text { (minimum } 10 \text { cores per biopsy } \\
\text { sample) }\end{array}$ & $\begin{array}{l}\text { PSAV }>1 \mathrm{ng} / \mathrm{ml} \text { per year, DRE, } \\
\text { rebiopsy sample Gleason score, } \\
\text { number of tumour-positve biopsy } \\
\text { sample cores, and maximum extent } \\
\text { of cancer per core all mentioned }\end{array}$ \\
\hline $\begin{array}{l}\mathrm{AHS}^{2} \\
\mathrm{AH}^{2}\end{array}$ & Low & $\begin{array}{l}\text { Tumour stage }<\text { T2b, serum } \\
\text { PSA }<10 \mathrm{ng} / \mathrm{ml}, \text { biopsy } \\
\text { Gleason score of }<7, \leq 3 \\
\text { tumour-positive biopsy }\end{array}$ & NR & $\begin{array}{l}\text { Serum PSA every } 3-6 \text { months, at } \\
\text { the physician's discretion, } \\
\text { serum PSA kinetics mentioned } \\
\text { DRE annually, at the physician's }\end{array}$ & $\begin{array}{l}\text { Switching recommended if PSAD } \\
<3 \text { years, increase in clinical stage } \\
\text { from baseline status is observed on } \\
\text { DRE, Gleason pattern } \geq 4 \text { observed }\end{array}$ \\
\hline
\end{tabular}




\begin{tabular}{|c|c|c|c|c|c|}
\hline & & $\begin{array}{l}\text { core samples } \leq 50 \% \text { tumour } \\
\text { positivity per biopsy core, } \\
>10 \text { cores sampled }\end{array}$ & & $\begin{array}{l}\text { discretion } \\
\text { repeat biopsy sampling 1-2 years } \\
\text { after initial diagnosis, } \\
\text { further biopsy sampling every } 2-3 \\
\text { years, or as clinically indicated }\end{array}$ & $\begin{array}{l}\text { on analysis of rebiopsy samples, } \\
>50 \% \text { of cancer observed per core } \\
\text { biopsy sample, also taking into } \\
\text { account patient preferences }\end{array}$ \\
\hline $\mathrm{CCO}_{4}^{2}$ & Low & $\begin{array}{l}\text { Tumour stage } \leq \text { T2a, serum } \\
\text { PSA }<10 \mathrm{ng} / \mathrm{ml} \text {, biopsy } \\
\text { Gleason score of } \leq 6 \text { or } \\
3+4=7 \text { (for selected } \\
\text { patients) }\end{array}$ & NR & $\begin{array}{l}\text { Serum PSA every } 3-6 \text { months, } \\
\text { DRE measured annually } \\
\text { 12-14-core confirmatory TRUS } \\
\text { biopsy within } 6-12 \text { months post- } \\
\text { biopsy, then serial biopsy a } \\
\text { minimum of every } 3-5 \text { years } \\
\text { thereafter, MRI mentioned }\end{array}$ & $\begin{array}{l}\text { Rebiopsy sample Gleason score } \geq 7 \\
(4+3 \text { or } 3+4) \text { with pattern } 4 \\
\text { pathology accounting for }>10 \% \text { of } \\
\text { the total tumour or } 3+\text { and } / \text { or } \\
\text { significant increases in the } \\
\text { volume of Gleason } 6 \text { tumours }\end{array}$ \\
\hline $\begin{array}{l}\mathrm{NCC} \\
\mathrm{S}^{21}\end{array}$ & Low & $\begin{array}{l}\text { Tumour stage } \leq \mathrm{T} 2 \mathrm{a} \text {, serum } \\
\text { PSA }<10 \mathrm{ng} / \mathrm{ml} \text {, biopsy } \\
\text { Gleason score of } \leq 6 \text { (no } \\
\text { Gleason grade } 4 \text { or } 5 \text { ), } \\
\text { serum PSA density of } \\
<0.15,<3 \text { tumour-positive } \\
\text { biopsy core samples, } \leq 50 \% \\
\text { tumour positivity per } \\
\text { biopsy core }\end{array}$ & $\begin{array}{l}\mathrm{LE}<10 \\
\text { years }\end{array}$ & $\begin{array}{l}\text { Serum PSA measurements every } 3- \\
6 \text { months, annual DRE, rebiopsy } \\
\text { sampling within the first 12-18 } \\
\text { months post-diagnosis, if no } \\
\text { adverse features are observed after } \\
2 \text { years, this interval can be } \\
\text { increased }\end{array}$ & $\begin{array}{l}\text { Switching recommended of } \\
\text { abnormalities or change observed on } \\
\text { DRE, increase in GS } \geq 7 \text { or any patter } \\
4 \text { or } 5 \text { observed on rebiopsy sampling } \\
>2 \text { tumour positve biops core sample } \\
>50 \% \text { of cancer observed per core } \\
\text { biopsy sample, also taking into } \\
\text { account patient preferences }\end{array}$ \\
\hline $\mathrm{PCT}^{22}$ & $\begin{array}{l}\text { Very } \\
\text { low }\end{array}$ & $\begin{array}{l}\text { Tumour stage T1a,T1c, } \\
\text { serum PSA }<10 \mathrm{ng} / \mathrm{ml}, \\
\text { biopsy Gleason score of } 6 \text {, } \\
\text { PSA density }<0.15,<3 \\
\text { tumour positive biopsy } \\
\text { core samples, }<50 \% \\
\text { tumour positivity per } \\
\text { biopsy sample }\end{array}$ & $\begin{array}{l}\text { LE, } \\
\text { disease } \\
\text { characte } \\
\text { ristics, } \\
\text { general } \\
\text { health } \\
\text { conditio } \\
\text { n, } \\
\text { potentia } \\
\text { l side } \\
\text { effects } \\
\text { of } \\
\text { treatme } \\
\text { nt, } \\
\text { patient } \\
\text { preferen } \\
\text { ce } \\
\text { mention } \\
\text { ed }\end{array}$ & $\begin{array}{l}\text { Serum PSA measurements every } 6 \\
\text { months, or every } 3 \text { months if } \\
\text { concerns exist regarding disease } \\
\text { progression, PSA kinetics and DRE } \\
\text { mentioned, rebiopsy sampling } \\
\text { recommended within } 12 \text { months of } \\
\text { initial biopsy sampling or as } \\
\text { clinically indicated }\end{array}$ & NR \\
\hline & Low & $\begin{array}{l}\text { Tumour stage T1-T2a, } \\
\text { serum PSA }<10 \mathrm{ng} / \mathrm{ml} \text {, } \\
\text { biopsy Gleason score of } 6\end{array}$ & $\begin{array}{l}\text { LE } \\
\text { mention } \\
\text { ed }\end{array}$ & & \\
\hline $\begin{array}{l}\text { PCFA } \\
25\end{array}$ & & $\begin{array}{l}\text { Tumour stage T1-T2, } \\
\text { serum PSA } \leq 20 \mathrm{ng} / \mathrm{ml} \\
\text { biopsy Gleason score of } 6\end{array}$ & NR & NR & NR \\
\hline \multicolumn{6}{|c|}{$\begin{array}{l}\text { AHS, Alberta Health Services; AUA, American Urological Association; CCNS, Cancer Care Nova Scotia; CCO, Cancer Care } \\
\text { Ontario; DUA, Dutch Urological Association; EAU, European Association of Urology; FCCG, The Finnish Medical Society } \\
\text { Duodecim; GSU, German Society of Urology; I+CS, Aragon Institute of Health Sciences; KCE, Belgian Healthcare Knowledge } \\
\text { Centre; LE, life expectancy; NCCN, The National Comprehensive Cancer Network; NCCS, National Cancer Centre Singapore; NICE, } \\
\text { National Institute for Health and Clinical Excellence; NR, not reported; PCFA, Prostate Cancer Foundation of Australia, PCT; } \\
\text { Prostate Cancer Taskforce; PEBC, Program in Evidence-Based Care; PSADT, PSA doubling time; PSAV, PSA velocity; SCAN, } \\
\text { South East Scotland Cancer Network }\end{array}$} \\
\hline
\end{tabular}


Box 1. Members of the Movember Global Action Plan consortium

Ehdaie, Behfar Memorial Sloan Kettering Cancer Center, New York, USA

Fahey, Michael Epworth HealthCare, Melbourne, Australia

Filson, Christopher Emory University School of Medicine, Atlanta, USA

Frydenberg, Mark Monash University, Melbourne, Australia

Gnanapragasam, Vincent Cambridge University Hospitals NHS Trust, Cambridge, UK

Kakehi, Yoshiyuki Kagawa University Faculty of Medicine, Kagawa, Japan

Kattan, Mike Cleveland Clinic, Cleveland, USA

Klotz, Laurence University of Toronto, Sunnybrook Health Sciences Centre, Toronto, Canada

Lophatananon, Artitaya University of Manchester, Manchester, UK

Malouf, David Sydney Prostate Cancer Center, Sydney, Australia

Moore, Caroline University College London \& University College London Hospitals Trust, London, UK

Muir, Kenneth University of Manchester, Manchester, UK

Parker, Chris Institute of Cancer research, The Royal Marsden, London, UK

Pickles, Tom University of British Columbia, British Colombia Cancer Agency, Vancouver, Canada

Sanda, Martin Emory University School of Medicine, Atlanta, USA

Steyerberg, Ewout Erasmus MC, Rotterdam, Netherlands

Trock, Bruce Johns Hopkins University, Baltimore, USA

Valdagni, Riccardo Fondazione IRCCS Istituto Nazionale dei Tumori di Milano, Milan, Italy

van der Kwast, Theo Princess Margaret Cancer Centre, Toronto, Canada

Villers, Arnauld Centre Hospitallier Regional Universitaire de Lille, Lille, France

Wicklin Gillespie, Theresa Emory University School of Medicine, Atlanta, USA

Zhang, Liying Sunnybrook Health Sciences Centre, Toronto, Canada 
Box 2. Unresolved issues in active surveillance

Inclusion

- Inclusion of men with stage T2b-c or T3, serum PSA >10 ng/ml and with Gleason $7(3+4)$ cancer

- Serum PSA density, the minimum number of cores sampled, the patient's life expectancy, the presence of comorbidities, and patient's preferences as risk stratification tools

- Potential role of new biomarkers in selecting men for active surveillance (including genomics)

- The role of MRI in selecting men for active surveillance

- The role of quality of life in the decision to initially pursue active surveillance rather than active treatment

- A validated, multivariate risk assessment tool for definitions of 'low-risk' disease

\section{Patient monitoring and triggers for treatment}

- Optimal timing of surveillance monitoring strategies (frequency of serum PSA measurement, DRE and repeat biopsy) while on active surveillance

- The role of multiparametric MRI in predicting prostate cancer progression

- The role of serum PSA kinetics as a trigger for intervention

- Definitions of disease reclassification and progression

- The role of novel biomarkers and monitoring tools in risk assessment during active surveillance

- The role of quality of life in the decision to switch from active surveillance towards active treatment 